\title{
KELUARGA BERENCANA DI KALANGAN KELUARGA PESANTREN DALAM MEMBENTUK KELUARGA SAKINAH \\ (Studi Fenomenologis Di Pondok Pesantren Bahrul Ulum Tambak Beras Jombang)
}

\author{
Umi Sumbulah dan Nining Eka Wahyu Hidayati \\ Fakultas Syariah UIN Malang \\ Jl. Gajayana 50 Malang \\ (0341-559399)
}

\begin{abstract}
Abstrak
This research aims to understand the reason of Pesantren Bahrul Ulum family of Tambak Beras Jombang to participate in family planning program, to decide participating in the program and the implication of the program on establishing harmonious family among the pesantren family. The result of this research reveals that the reason of participating family planning program can be classified into several aspects such as health, psychology, economy, religion and education. Nonetheless, health factor is the most dominant factor. To make decision to participate in the program, the family of the pesantren build intensive two-side communication (so-called "musyawarah"). There are two implications (positive and negative) of famili planning program in relation with establishing harmonious family. One of the positive implication is the understanding that harmonious family may be established if a wife (mother) is not busy with domestic affair due to pregnancy and giving birth many times. As a result, the parents may concern with children's education.Then, for the negative implication is that health problem affecting to the spouse relationship which tend to be uncomfortable.
\end{abstract}

\section{A. Konteks Penelitian}

Keluarga pesantren adalah keluarga yang terlahir dari keturunan kyai yang memiliki pesantren dan hidup berada dalam lingkungan pesantren. Pada umumnya keluarga pesantren adalah menjadi pengasuh dan pendidik dalam pesantern. Keluarga pesantren adalah tokoh masyarakat yang sangat dihormati dan disegani dalam masyarakat, biasanya masyarakat menyebutnya ulama atau kyai. Para ulama sangat mempunyai pengaruh yang sangat besar dalam masyarakat karena para ulama sebagai panutan dan suri tauladan yang baik yang patut untuk dicontoh. Maka dari itu setiap tingkah laku para ulama adalah menjadi pijakan bagi masyarakat. Seperti contoh dalam mengikuti program KB (keluarga berencana). Pro-kontra tentang program KB dalam masyarakat Islam telah menjadi polemik yang kunjung selesai. Dimulai sejak pemerintahan mencanangkan Program KB tahun 1968 hingga hari ini. ${ }^{1}$ Terdapat pro-kontra apabila berbicara tentang KB di kalangan ulama ada yang mendukung ada pula yang tidak mendukung terhadap program tersebut. Seperti yang dikemukakan oleh

\footnotetext{
${ }^{1}$ Thariq At-Thawari, "KB Cara Islam”, (Solo: PT. Aqwam Media Profetika, 2007), v.
} 
ulama-ulama di Indonesia. Menurut Nasarudin, para tokoh agama Islam telah menyatakan dukungan terhadap program KB, yaitu dengan keputusan Musyawarah Nasional Majelis Ulama Indonesia (Munas MUI). Ketua Umum Pengurus Besar Nahdlatul Ulama (PBNU) Hasyim Muzadi mengatakan Nahdlatul Ulama (NU) mendukung program Keluarga Berencana (KB). "Untuk kemaslahatan keluarga dan umum". Perlunya pelaksanaan KB, kata beliau, untuk memelihara kesehatan ibu dan anak serta terjaminnya kebutuhan ekonomi dan pendidikan yang layak. "Karena dalam Islam ada konsep keluarga sakinah" 2 menurut fatwa Syaikh Ibnu Utsaimin dan Syaikh Abdul Azin bin Baz mereka juga mendukung program tersebut apabila hal itu bersifat dharurat. KB memiliki peran atau pembawa manfaat terhadap keharmonisan keluarga dalam membentuk keluarga yang berkualitas menuju keluarga sakinah.

Di kalangan keluarga pesantren terdapat kelompok yang pro-kontra terhadap program KB karena kebanyakan dari mereka masih berlandaskan pada hadits nabi Muhammad SAW tersebut, yakni anak banyak yang membanggakan. Tetapi pada saat ini terdapat sebagian keluarga pesantren (keluarga para ulama) yang pro terhadap KB, seperti contoh pesantren Bahrul Ulum Tambak Beras Jombang yang mengikuti program KB. Karena menurut mereka terdapat alasan-alasan yang sangat kuat dalam segi pendidikan, kesehatan dan psikologi. Segi kesehatan, menurut dokter dalam usia 35 tahun adalah usia rawan untuk hamil dan melahirkan bagi perempuan, karena pada usia tersebut tingkat kondisi tubuh menurun. Setiap orang hamil harus mempunyai daya tubuh yang kuat untuk melahirkan dan apabila mereka tidak mempunyai daya tubuh yang kuat maka hal itu dapat membahayakan bagi ibu dan anak. Di samping itu juga apabila dilihat dari segi psikologisnya, setiap orang tua haruslah adil dalam membagi rasa kasih sayang terhadap setiap anak-anaknya. Orang hamil pada umumnya tingkat kondisi emosional tidak stabil apabila hal terus menerus hamil, maka dikhawatirkan akan dapat berakibat buruk terhadap pendidikan dan merawat anakanaknya. Maka dari alasan-alasan diatas keluarga pesantren Bahrul Ulum memutuskan untuk mengikuti program KB. Dalam proses memutuskan KB ini keluarga pesantren melihat pandangan-pandangan ulama mengenai $\mathrm{KB}$ dan melihat segi kemaslahatannya. Tidak ada gerakan tersendiri di kalangan keluarga pesantren dalam mengikuti program KB.

Keluarga pesantren Bahrul Ulum juga berpandangan bahwa mengikuti program KB adalah tidak masalah. Hukum Islam membolehkan karena tokoh masyarakat sangat

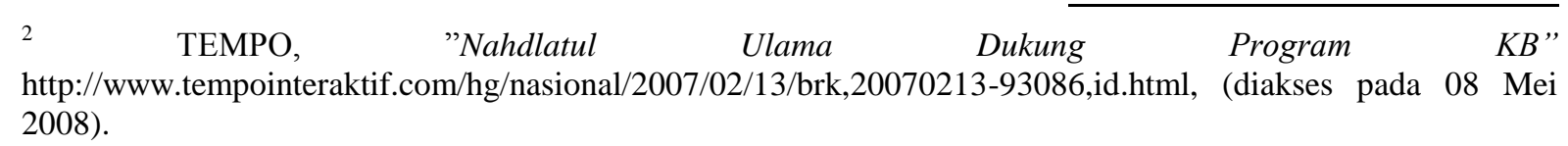


diperlukan untuk menggerakkan dan memberikan motivasi kepada masyarakat dalam mengikuti program KB nasional. Karena dengan KB jarak kelahiran anak dapat diatur yang akhirnya akan menjadi keluarga yang sakinah dan berkualitas.

Program keluarga berencana, pencegahan kehamilan, serta pembatasan kelahiran selalu menempatkan masyarakat ke dalam dua sudut pandang yang berbeda, yaitu: yang setuju dan yang menolak. Dana yang melimpah, intitusi yang kuat, dan pengawasan pelaksanaan oleh aparat membuat program ini seolah-olah mengekang dan mencampuri urusan domestik keluarga. ${ }^{3}$ Keluarga Berencana $(\mathrm{KB})$ berarti pasangan suami isteri telah mempunyai perencanaan yang konkrit mengenai kapan anak-anaknya diharapkan lahir agar setiap anaknya lahir disambut dengan rasa gembira dan syukur. Pasangan suami istri tersebut juga telah merencanakan berapa anak yang dicita-citakan, yang disesuaikan dengan kemampuannya sendiri dan situasi dan kondisi masyarakat dan negaranya. ${ }^{4}$

KB secara substansial tidak bertentangan dengan ajaran Islam bahkan salah satu bentuk implementasi semangat ajaran Islam dalam rangka mewujudkan sebuah kemaslahatan, yaitu menciptakan keluarga yang tangguh, sakinah, mawaddah dan penuh rahmah. Keluarga akan melahirkan bangsa yang tangguh. Kebolehan hukum ber-KB, sudah menjadi kesepakatan para ulama dalam forum-forum keislaman, baik tingkat nasional maupun internasional (Ijma"al-majami'). ${ }^{5}$

Dari konteks penelitian diatas, maka peneliti merasa tertyarik untuk meneliti dan mengkaji materi tersebut dan dalam penelitian ini, peneliti memfokuskan pada pandangan keluarga pesantren tentang keluarga berencana di kalangan keluarga pesantren. Pada umumnya terjadi indikasi pro dan kontra pada sebagian para ulama tentang program KB ada yang mendukung dan ada sebagian juga yang tidak mendukung terhadap program tersebut. Dan sejauh ini pula peneliti juga ingin mengetahui sejauh mana peran program berencana tersebut dalam membentuk keluarga sakinah di kalangan keluarga pesantren, serta implikasinya dalam membentuk keluarga sakinah.

\section{B. Tujuan Penelitian}

Penelitian ini bertujuan: pertama, memahami faktor-faktor yang menyebabkan alasan keluarga pesantren di lingkungan PP Bahrul Ulum Tambakberas Jombang tentang mengaplikasikan program keluarga berencana $(\mathrm{KB})$ dalam proses membentuk keluarga sakinah; kedua, memahami pengambilan kesepakatan terhadap keluarga yang mengikuti

\footnotetext{
${ }^{3}$ Thariq At-Thawari, Op. Cit., viii.

${ }^{4}$ Masjfuk Zuhdi, Masail Fiqhiyah (Jakarta: PT. Midas Surya Grafindo, 1997), 55

5 BKKBN, "KB Tidak Bertentangan Dengan Ajaran Islam", http://www.bkkbn.go.id/gemapria/info.detail.php?infid=29 (diakses pada 08 Mei 2008).
} 
program KB di kalangan keluarga pesantren di lingkungan PP Bahrul Ulum Tambakberas Jombang; ketiga, memahami implikasi keluarga berencana bagi pembentukan keluarga sakinah di kalangan keluarga pesantren di lingkungan PP Bahrul Ulum Tambakberas Jombang

\section{Metode Penelitian}

\section{Pendekatan dan Jenis Penelitian}

Pendekatan penelitian ini adalah fenomenologi karena berupaya memahami arti peristiwa dan kaitan-kaitannya terhadap orang-orang yang berada dalam situasi-situasi tertentu, fenomenologi juga merupakan pandangan berpikir yang menekankan pada fokus kepada pengalaman-pengalaman subjektif manusia dan interpretasi-interpretasi dunia. ${ }^{6}$ Adapun jenis pendekatan pada penelitian ini menggunakan jenis penelitian kualitatif, karena berupaya untuk memahami prilaku manusia dari segi kerangka berfikir maupun bertindak orang-orang itu sendiri yng difokuskan pada informasi dari data-data deskriptif (kata-kata tertulis atau lisan dari informan), bukan data numerik yang membutuhkan analisis statistik.

\section{Sumber Data}

a. Data Primer

Data primer dalam penelitian ini adalah data-data yang diperoleh dari objek penelitian secara langsung dengan menggunakan metode wawancara atau interview yang dilakukan dengan orang-orang yang melakukan program keluarga berencana $(\mathrm{KB})$ yaitu dari kalangan keluarga pesantren seperti pasangan: bapak KH. Yahya Husnan dan ibu nyai Hj. Umy Salamah, bapak KH. Muhammad Idris Djamaluddin dan ibu nyai Hj. Muhimmatul Falasifah, bapak Drs. KH. Abdul Choliq Hasan M. Hi dan ibu nyai Hj. Bashirotul Hidayah S.Ag, bapak KH. Hasyim Yusuf dan ibu nyai Hj. Lathifah Hidayati, bapak KH. Irfan S.Pd dan ibu nyai Dra. Hj. Siti Fatihah, bapak KH. Nashir Abd Fattah dan ibu nyai Hj. Ummu Salmah.

b. Data sekunder

Data sekunder mencakup dokumen-dekumen resmi, buku-buku, hasil-hasil penelitian yang berwujud laporan, dan sebagainya. Dalam hal ini peneliti menggunakan buku-buku yang berkaitan dengan masalah KB dan keluarga sakinah dan dokumen-dokumen lain yang mendukung penelitian ini seperti foto-foto, data-data dari PP. Bahrul Ulum Tambak Beras Jombang.

\section{Metode Pengumpulan Data}

${ }^{6}$ Lexy J. Moleong, Op.Cit., 15-17. 
a. Wawancara

Dalam hal ini yang menjadi informannya adalah pasangan kyai dan nyai seperti bapak KH. Yahya Husnan dan ibu nyai Hj. Umy Salamah, bapak KH. Muhammad Idris Djamaluddin dan ibu nyai Hj. Muhimmatul Falasifah, bapak Drs. KH. Abdul Choliq Hasan M. Hi dan ibu nyai Hj. Bashirotul Hidayah S.Ag, bapak KH. Hasyim Yusuf dan ibu nyai Hj. Lathifah Hidayati, bapak KH. Irfan S.Pd dan ibu nyai Dra. Hj. Siti Fatihah, bapak KH. Nashir Abd Fattah dan ibu nyai Hj. Ummu Salmah.

b. Teknik Dokumentasi

Dokumen merupakan catatan peristiwa yang sudah berlalu. Dokumen bisa berbentuk tulisan, gambar, taau karya-karya monumental dari seseorang. Dokumen yang berbentuk tulisan, misalnya catatan harian, sejarah kehidupan, cerita, biografi, peraturan, kebijakan. Dokumen yang berbentuk gambar, misalnya foto, gambar hidup, sketsa, dan lainlain. Dokumen yang berbentuk karya seni, yang dapat berupa gambar, patung, film, dan lainlain.

c. Observasi

Dalam hal ini peneliti menggunakan teknik wawancara, dokumentasi dan observasi dengan mengumpulkan dan mempelajari data-data yang telah diperoleh dalam buku-buku literatur mengenai keluarga berencana $(\mathrm{KB})$, keluarga sakinah dan pesantren. Peneliti juga mengamati setiap prilaku-prilaku yang terjadi di dalam keluarga pesantren yang mengikuti program KB.

\section{Pengolahan dan Analisis Data}

Setelah data-data yang berkaitan dengan masalah keluarga berencana (KB) dan keluarga sakinah diperoleh melalui proses tersebut diatas, maka tahapan selanjutnya yaitu menganalisis data dengan menggunakan analisis deskriptif dan setelah itu mengolah data-data yag sudah diperoleh di lapangan. Untuk menghindari banyaknya kesalahan serta untuk mempermudah pemahaman, maka peneliti menggunakan lima tahap pengelohan dan analisis data, yakni: editing, classifying, verifying dan analysing serta concluding.

\section{E. Paparan dan Analisa Data Tentang Keluarga Berencana di Kalangan Keluarga Pesantren Dalam Membentuk Keluarga Sakinah}

\section{Alasan KB di Keluarga Pesantren PP. Bahrul Ulum Tambak Beras Jombang.}

Umumnya, seseorang yang mengikuti program KB karena terdapat alsasn-alasan yang kuat yang dijadikan landasan dalam mengikuti program keluarga berencana (KB), di antaranya adalah di bawah ini: 


\section{a. Kesehatan}

Kesehatan merupakan salah satu alasan yang paling dominan yang diadikan landasan keluarga pesantren PP. Bahrul Ulum Tambak Beras Jombang dalam mengikuti program KB sebagaimana yang dipaparkan di bawah ini:

Pasangan bapak KH. Yahya Husnan dan ibu nyai Hj. Umy Salamah yang berhasil ditemui dan diwawarai oleh peneliti, dan ternyata beliau menanggapi dengan sangat antusias dan responsif. Selanjutnya peneliti langsung menanyakan alasan apa yang dijadikan landasan beliau dalam mengikuti program keluarga berencana $(\mathrm{KB})$ :

"Saya ini kan anaknya sudah 4 sebelum saya MOWkan itu 4 anak saya terus kemudian usia saya, terus saya hamil lagi setelah itu anak yang ke lima usia saya sudah 37 tahun menurut dokter uasia segitu itu usai rawan, rawan untuk melahirkan. Untuk hamil memang sudah semestinya kalau teori teori dokter itu 35 itu sudah harusnya tidak hamil lagi orang perempuan itu nah saya itu usia segitu masih hamil kemudian lagi ketika di USG ternyata anak saya kembar, akhirnya terus saya tapi itu terus begini saya waktu hamilnya ke 4 saja itu sudah capek sekali sudah banyak sekali yang keluhan itu sudah banyak capek terus capek itu saya kira pasti setiap ngelahirin capek tapi maksudnya itu kondisi itu sudah menurun jadi saya itu sampe mengalami istilahe apa ya istilahnya dokter itu saya lupa pokoknya kontraksi-kontraksi itu ibu hamil sebelum melahirkan itu sudah mulai itu anak yang ke 4 terus setelah itu saya melahirkan terus 2 tahun kemudian saya hamil lagi pada waktu saya hamil yang terakhir ini justru luweh (tambah) masalah terus saya bermasalah sekali sudah mulai hamil 8 bulan 7 bulan berapa bulan itu saya sdah tidak kuat apa-apa terus mendekati ya sudah 8 bulan mendekati 9 bulan itu saya sudah tidak bisa sholat dalam arti tidak bisa duduk di bawah ndak (tidak) bisa, jadi sholat saya duduk di kursi, tersu setelah itu mendekati lagi semakin mendekat kelahiran semakin saya sakit malah akhirnya menjelang melahirkan itu saya tidak bisa apa-apa sampek di atas bayang (tempat tidur) ndak bisa obah (bergerak) ndak bisa turun pipis (kencing) di pispot seperti itu lah dengan kondisi seperti itu ya itu kalau menurut saya sudah ndak apa-apa jadi sudah punya alasan untuk berhenti punya anak. Karena saya punya alasan kuat saya merasa le aku selalu hamil, saya ikutan potongane-potongan subur (orang yang subur) jadi nggak kenean weih diluk wes (tidak bisaan jadi sebentar sudah) hamil hamil lah dengan kondisi sering hamil seperti itu. Anu (jadi) emosional saya merasa ketika hamil itu anak iku enggak keramut (itu tidak terawat) saya sibuk dengan diri saya sendiri dewngan kesakitan saya sendiri justru saya dengan keadaan seperti itu saya merasa berdosa karena saya menyia-nyiakan amanah yang sudah diberikan oleh Allah ini kan gernerasi yang harus dididik untuk menjadi anak yang baik saya sia-siakan apakah itu tidak lebih berdosa lah karena itu perempuan juga mempunyai hak kan untuk menjaga kesehatannya sendiri untuk menjaga reproduksinya sendiri demi kelangsungan yang lebih maslahat itu pertimbangan saya. ${ }^{7}$

Di waktu yang lain peneliti mewawancarai suami ibu nyai $\mathrm{Hj}$. Umi Salamah.

Peneliti juga menanyakan alasan beliau mengizinkan istrinya mengikuti program keluarga

\footnotetext{
${ }^{7}$ ibu nyai Hj. Umy Salamah, Wawancara (Jombang, 10 Mei 2008).
} 
berencana (KB):"kesehatan, gawe coro kesehatan jarene wes rawan soale umure wes diatas 35 mari ngunu terus anu op jenenge kesibukannya ngurusi anak". ${ }^{8}$

Pasangan bapak KH. Muhammad Idris Djamaluddin dan ibu nyai $\mathrm{Hj}$. Muhimmatul Falasifah memberikan alasannya mengikuti program KB adalah :

"Mantun ngelahiraken maleh niku boleh kKB terus izin cuman karena untuk penjarangan jarak kelahiran biar gak terlalu dekat, ngeh piye-piye kulo tigo niku setengah setelah lahir, dadi bayi 10 bulan hamil jadi setahun setengah niku lahir."9

Pasangan KH. Hasyim Yusuf dan ibu nyai Hj. Lathifah Hidayati, menjawab:

"Antara jarak satu antara anak pertama dan anak kedua itu terlalu dekat sehingga, terus hanya terpaut 1 setengah tahun anak saya itu jadi sebenarnya saya pengen menyusui anak saya selama 2 tahun, bukan terus tidak pengen punya anak enggak (tidak) hanya untuk jara'i (memberi jarak) saja tapi ternyata setelah saya pakek ke IUD sampek tiga bulan tok saya lepas karena ketidaknyamanan perasaan ya, saya gak (tidak) nyaman. Ya itu maenga (tadi), hanya untuk jaraknya saja supaya tidak dekat seperti itu, bukan berarti saya tidak ingin punya anak lagi nadak (tidak) hanya jarak memberikan jarak antara anak pertama dengan anak kedua itu". ${ }^{10}$

Peneliti juga melakukan wawancara terstruktur kepada suami beliau yaitu bapak KH. Hasyim Yusuf, selanjutnya peneliti menanyakan alasan beliau mengizinkan istrinya mengikuti program keluarga berencana $(\mathrm{KB})$ :

"Pernah dulu ikut KB, yang intinya ikut KB itu hanya untuk biar tidak terlalu cepat mempunyai anak (istilahe (istilahnya) untuk ngelet-ngeleti (jarak) ikut KB saya izinkan asalkan sebatas tidak mematikan benih hanya tadi itu untuk jarak". ${ }^{11}$

Pasangan bapak Drs. KH. Abdul Choliq Hasan M. Hi dan ibu nyai Hj. Bashirotul Hidayah S.Ag saat ditemui peneliti, ternyata hanya ibu nyai Hj. Bashirotul Hidayah S.Ag saja yang bisa diwawancarai, bahwa "Mengatur jarak kelahiran agar kelahiran tidak terlalu padat dan ingin menyusui dengan masa susuan maksimal (2 tahun)". ${ }^{12}$ Pasangan KH. Nashir Abd Fattah dan ibu nyai Hj. Ummu Salmah menanggapi pertanyaan peneliti mengenai landasan beliau dalam mengikuti program keluarga berencana $(\mathrm{KB})$ : "untuk mengatur jarak kelahiran". ${ }^{13}$ Sedangkan pasangan bapak KH. Irfan S.Pd dan ibu nyai Dra. Hj. Siti Fatihah menanggapi: "Yo biar ndak terlalu brindil (banyak anak) tau ndak (tidak) brindil (banyak anak) terus menerus maksudnya ada jarak"14

\footnotetext{
${ }^{8}$ KH. Yahya Husnan, Wawancara (Jombang, 10 Mei 2008).

${ }^{9}$ ibu nyai Hj. Muhimmatul Falasifah, Wawancara (Jombang, 10 Mei 2008).

${ }^{10}$ Ibu nyai Hj. Lathifah Hidayati, Wawancara (Jombang, 29 November 2008).

${ }^{11}$ KH. Hasyim Yusuf, Wawancara (Jombang, 29 November 2008).

${ }^{12}$ Ibu nyai Hj. Bashirotul Hidayah S.Ag, Wawancara (Jombang, 10 Mei 2008).

${ }^{13}$ Ibu nyai Hj. Ummu Salmah, Wawancara (Jombang, 06 Desember 2008).

${ }^{14}$ Ibu nyai Dra. Hj. Siti Fatihah, Wawancara (Jombang, 06 Desember 2008).
} 
Dalam penelitian ini sebagian besar alasan keluarga pesantren mengikuti program KB yang paling dominan adalah karena kesehatan. Terlalu sering hamil dan melahirkan , perempuan yang sudah punya lebih dari empat anak dihadang bahaya kematian akibat pendarahan hebat dan macam-macam kelainan lain, apabila terus saja hamil dan bersalin lagi. Hal ini selaras dengan pengakuan ibu nyai $\mathrm{Hj}$. Umi Salamah yang mengatakan bahwa alasan beliau dalam mengikuti program KB karena usia beliau yang sudah mencapai 37 tahun. Menurut teori kedokteran usia 35 tahun ke atas adalah usia yang rawan untuk hamil dan melahirkan. Semestinya perempuan yang usianya sudah terlalu tua untuk mengandung dan melahirkan terancam banyak bahaya. Khususnya bila ia mempunyai problema-problema kesehatan lain, atau sudah terlalu sering hamil dan melahirkan. Alasan kesehatan lainnya dari mereka yaitu mengetur jarak dan merencanakan kelahiran antara anak pertama dan keputusan anak selanjutnya, hal ini seperti yang dituturkan oleh ibu nyai. Falasifah, bapak KH. Hasyim ibu nyai Hj. Lathifah, ibu nyai Bashirotul, ibu nyai $\mathrm{Hj}$. Salmah dan ibu nyai $\mathrm{Hj}$. Fatihah. Kebanyakan dari alasan mereka adalah untuk mengatur jarak kelahiran agar kelahiran tidak terlalu padat dan ingin menyusui dengan masa susuan maksimal (2 tahun).

Pada dasarnya Islam membolehkan umatnya ber KB. ${ }^{15}$ Jika mengetahu dan memahami betul maksud dan hikmah Islam dibalik pemberian keringanan atas pelaksanaan hubungan terputus pada berbagai kondisi darurat adalah karena terinspirasi dari pemahaman yang sempurna bahwa seorang anak menjadi tanggung jawa yang sangat besar dan wajib dipelihara dengan pemeliharaan yang sempurna dan kepedulian tinggi, atau karena alasan bahwa kelahiran seorang anak akan membahayakan sang ibu bahkan ancaman kematian.

Sesuai dengan ilmu kesehatan, ibu hendaknya mengatur jarak antara dua kehamilan atau kelahiran minimal dua setengah tahun dan bisa dibulatkan tiga tahun sebagai jarak antara kehamilan atau kelahiran memang baik menurut ilmu kesehatan, karena ibu memerlukan waktu tersebut untuk menjaga kesehatan padawaktu hamil agar kandungannya selamat dan ia perlu menyusui dan merawat bayinya dengan seksama. Kemudian ia juga perlu merehabilitasi (memperbaiki) dirinya sendiri. ${ }^{16}$

Di samping itu, pertumbuhan seorang anak pada masa menyusui jugaterancam bila sang ibu hamil lagi. Dalam kondisi-kondisi seperti di atas bila seseorang menggunakan salah satu cara atau alat untuk mencegah kehamilan setelah mendapat petunjuk dari dokter yang terpercaya, tidak mengapa kalau dia melakukan hal tersebut. Melaksanakan KB dengan motivasi yang hnaya bersifat pribadi, misalnya ber-KB untuk menjarangkan kehamilan atau

15 Masjfuk Zuhdi, Masail Fiqhiyah (Jakarta: PT. Midas Surya Grafindo, 1997), 55-56.

${ }^{16}$ Ibid., 61. 
kelahiran, untuk menjaga kesehatan badan si ibu, hukumnya boleh saja. ${ }^{17}$ Dalam hidup berumah tangga, kesehatan sangat penting sekali artinya. Bahkan tidak hanya dalam hidup berumah tangga, tetapi bagi manusia seluruhnya. Oleh sebab itu, suami istri harus memlelihara kesehatan jasmani dan rohani agar dapat melaksanakan tugas masing-masing. ${ }^{18}$

\section{b. Psikologis}

Dari alasan segi psikologisnya hanya ada beberapa keluarga saja yang mempunyai alasan tersebut di atas.Pasangan bapak KH. Yahya Husnan dan ibu nyai Hj. Umi Salamah. Ibu nyai $\mathrm{Hj}$. Umi Salamah menjawab alasan beliau menngikuti program KB dari segi psikologisnya, yaitu:

"Alasan lain, itu alasan fisik alasan yang kedua. Saya merasa orang hamil itu kan mesti anu (itu)" ya apa namanya reksoso (sehat) itu khusu untuk saya gak (tidak) tau orang lain ya emosi saya itu selalu naik gak (tidak) stabil yang jadi korban anak-anak, saya masih terus sama anak-anak, didekati gak (tidak) mau sering saya marahi anak-anak saya., tersu saya sendiri kurang bisa memperhatikan mereka". ${ }^{19}$

Pasangan bapak KH. Muhammad Idris Djamaluddin dan ibu nyai $\mathrm{Hj}$. Muhimmatul Falasifah memberikan alasan dan landasannya mengikuti program KB (keluarga berencana) dari segi psikologisnya,bahwa: "Memang secara psikologis anak itu kurang kasih sayang karena memang kesuburan jadi diizini sama suami Cuma itu tujuannya itu untuk penjarangan"

Selain dari alasan kesehatan terdapat juga alasan dari segi faktor psikologis. Seperti yang diungkapkan oleh ibu nyai Hj. Umi Salamah dan ibu nyai Hj. Muhimmatul Falasifah diatas. Bahwa alasan lain yang mendasari beliau mengikuti KB karena beliau merasa orang hamil itu emosinya selalu naiktidak stabil dan yang menjadi korban dari emosinya adalah ank-anak beliau sendiri, dan beliau merasa kurang bisa memperhatikan anak-anak beliau. Akibatnya, anak-anak kurang kasih sayang apabila beliau sering hamil dan melahirkan.

Anak merupakan hal yang sangat berharga di mata siapapun, khususnya orang tua. Anak adalah perekat hubungan di dalam keluarga, sehingga dapat dikatakan anak memiliki nilai yang tak terhingga. Banyak fenomena membuktikan orang tua rela berkorban demi keberhasilan anaknya. Tidak jarang ditemukan orang tua yang menghabiskan waktu, sibuk bekerja semata-mata untuk kepentingan anak.

Ditinjau dari sisi psikologi, kebutuhan anak bukan hanya sebatas kebutuhan materi semata, anak juga membutuhkan kasih sayang dan perhatian dari orang terdekatnya,

\footnotetext{
${ }^{17}$ Ibid., 57

${ }^{18}$ Dedi Junaedi, Keluarga Sakina Pembinaan dan Pelestariannya, (Jakarta: Akademika Pressindo, 2007), 180.

${ }^{19}$ Ibu nyai Hj. Umi Salama, Op.Cit.
} 
khususnya orang tua. Realitanya, banyak anak yang kurang mendapatkan kebutuhan afeksi (kasih sayang), disebabkan orang tua sibuk mencari uang demi untuk memperbaiki perekonomian keluarga.perbedaan persepsi inilah yang terkadang membuat dilema dalam hubungan antara orang tua dan anak menjadi semakin lemah.

Kedekatan hubungan antara orangtua dengan anak tentu saja akan berpengaruh secara emosional. Anak akan merasa dibutuhkan dan berharga dalam keluarga, apabila orangtua memberikan perhatiannya kepada anak. Anak akan mengganggap bahwa keluarga merupakan bagian dari dirinya yang sangat dibutuhkan dalam segala hal. Sebaliknya, hubungan yang kurang harmonis antara orangtua dan anak akan berdampak buruk terhadap perkembangan anak. Tidak jarang anak terjerumus ke hal-hal negatif dengan alasan orangtua kurang memberikan perhatian kpada anak.

Peran orangtua sangat dibutuhkan dalam perkembangan psikologi anak. Perhatian dan kedekatan orang tua sangat mempengaruhi keberhasilan anak dalam mencapai apa yang diinginkan. Orangtua merupakan pemberi motivasi terbesar bagi anak, sehingga diharapkan orangtua dapat memberikan perhatian dan kasih sayang sepenuhnya kepada anak. Kedekatan antara orangtua dan anak memiliki makna dan peran yang sangat penting dalam setiap aspek kehidupan keluarga. Oleh karena itu, kualitas dan kuantitas pertemuan antar anggota keluarga perlu ditingkatkan dengan tujuan untuk membangun keutuhan hubungan orangtua dan anak. ${ }^{20}$

\section{c. Ekonomi}

Dari alasan segi ekonominya hanya ada satu keluarga saja yang mempunyai alasan tersebut di atas di antranya yaitu: pasangan keluarga bapak KH. Yahya Husnan dan ibu nyai Hj. Umi Salamah. bapak KH. Yahya menjawab alasan beliau mengizinkan istrinya dalam mengikuti progam KB dari segi ekonominya: "Iku yo ekonomi barang ekonomikan tersalurkan nang kunu kabeh nang gone ngelahirkan". 21 "Itu ya ekonomi juga, ekonomikan tersalurkan di situ semua dibuat melahirkan”.(terj. penulis)

Alasan selanjutnya yaitu karena faktor ekonomi. Menurut penuturan bapak KH Yahya, apabila istrinya sering melahirkan ekonomi juga banyak tersalurkan pada proses persalinan tersebut.Salah satu faktor penting lainnya untuk mewujudkan keluarga sakinah yaitu dengan terpenuhinya kebutuhan ekonomi. Pemenuhuan kebutuhan ekonomi rumah

\footnotetext{
20 Iryanti, "Peran Orangtua dalam Mendidik Anak," http://www.pkpaindonesia. org/index.php?option=com_content\&view=article\&id=127:peran-orangtua $\quad$ alam mendidikanak\&catid=58:artikel-aceh\&Itemid=171, (diakes pada 31 Maret 2009). 1
} 
tangga merupakan salah satu usaha untuk mencukupi kebutuhan hidup sehari-hari. Dalam ajaran Islam pemenuhan kebutuhan ekonomi dapat disebut dengan nafkah.

Memberi uang belanja (nafkah) adalah hukumnya wajib untuk kehidupan seharihari bagi keluarga. Hal ini umumnya dibebankan kepada suami. Yang dimaksud dengan belanja (nafkah) di sini adalah memenuhi kebutuhan makanan, tempat tinggal, biaya kesehatan bagi seluruh anggota keluarga, biaya pendidikan dan pembantu rumah tangga bila si suami itu orang kaya. Sedangakan bila bukan orang kaya, maka sesuai dengan kemampuan, karena jumlah atau beberapa banyak uang yang harus diberikan kepada istri didasarkan pada penghasilan suami, tidak atas permintaan istri. Memberi nafkah ini hukumnya wajib (QS. al-Baqarah:233). Kuatnya kewajiban memberi nafkah dan besarnya pahala yang diterima suami, sampai dikatakan bahwa sesuap nasi yang diberikan kepada istri juga berpahala. Tentang ini, Rasulullah SAW menjelaskan bahwa belanja apapun yang diberikan kepada istri dengan tulus merupakan pahala, sedikit maupun banyak, sesuai dengan kemampuan.

Hal terpenting adalah agar suami tidak memberi makan istri dan keluarga kecuali dari harta yang di perolehnya secara halal. Karena bila memberikan harta haram maka itu merupakan perbuatan kejahatan terhadap mereka. Sejalan dengan ini, Islam mengajarkan bahwa suami hendaknya memberikan nafkah kepada istrinya secukupnya saja, tidak berlebihan dan tidak berkekurangan. 131 Orang tua (bapak dan ibu) harus memberikan nafkah yang baik, halal dan harus terhindar dari nafkah yang batil.

Selain meningkatkan ketrampilan untuk dapat mengahasilkan kebutuhan-kebutuhan ekonomi rumah tangga, seseorang harus terampil pula untuk mengatur jalannya ekonomi rumah tangga (manajemen ekonomi) agar seluruh pengahasilan itu dapat memenuhi sasaran kebutuhan sehari-hari. Sebab bagaimana pun banyak sumber penghasilan yang didapatkan namun bila tidak baik pengaturannya akan membawa kepada pemborosan.

\section{d. Agama}

Dari alasan segi agama hanya ada satu keluarga saja yang mempunyai alasan tersebut di atas diantranya yaitu: pasangan keluarga bapak KH. Muhammad Iddris Djamaluddin dan ibu nyai Hj. Muhimmatul Falasifah. Ibu nyai $\mathrm{Hj}$. Falasifah menjawab alasan beliau mengikuti progam KB dari segi agama yaitu: "Karena haji kemarin, terus tumut (ikut) KB 1 tahun“.

Sedangkan bapak KH. Muhammad Iddris Djamaluddin memberikan alasan beliau mengizinkan istrinya dalam mengikuti progam KB: "Ya karena kepentingannya untuk ibadah kan mau haji, jadi kalau secara umum yang dimaksud KB itu adalah seperti apa namanya 
membatasi keturunan sementara ini belum pertimbangan saya karena dia masih usia produktif. Tapi gak (tidak) tau saya belum bicara dengan dia".

Faktor agama juga termasuk alasan seseorang mengikuti dan melakukan progam $\mathrm{KB}$, hal ini seperti yang diungkapkan ibu nyai $\mathrm{Hj}$. Falasifah, beliau mengikuti KB karena alasan melakukan ibadah haji. Beliau tidak ingin terganggu selama malaksanakan ibadah haji di Makkah karena kedatangan bulan (haid). Maka suami beliau mengizinkan beliau untuk mengikuti KB.

Di dalam Al-Qur'an dan Hadits, yang merupakan sumber pokok hukum Islam dan yang menjadi pedoman hidup bagi umat Islam tidak ada nash yang sharih yang melarang ataupun yang memerintahkan ber-KB secara eksplisit. Karena itu, hukum ber-KB harus dikembalikan kepada kaidah hukum Islam (qaidah fiqhiyah) yang menyatakan bahwa: "Pada dasarnya segala sesuatu perbuatan itu boleh, kecuali ada dalil yang manunjukkan keharamannya”.

\section{e. Pendidikan}

Dari alasan segi pendidikan hanya ada satu keluarga saja yang mempunyai alasan tersebut di atas di antaranya yaitu: keluarga bapak KH. Yahya Husnan dan ibu nyai Hj. Umi Salamah. Ibu nyai $\mathrm{Hj}$. Umi menjawab alasan beliau mengikuti progam KB dari segi pendidikan yaitu:

"Saya juga kurang bisa mendidik mereka dengan baik jadi saya merasa, saya ini berdosa karena mereka semua titipan, lah karena mereka itu titipan dan amanah maka saya harus mendidik dengan baik kalau kondisi emosi tidak stabil tidak akan bisa mendidik dengan baik maka saya putuskan untuk saya berhenti punya anak saya karena saya kepingin mendidik anak-anakku dengan lebih baik lah seperti itu". ${ }^{22}$

Memiliki keturunan adalah salah satu daripada tujuan pernikahan. Insting untuk mendapatkan keturunan juga dimiliki oleh pria maupun wanita. Akan tetapi, perlu diketahui bahwa, mempunyai anak bukanlah suatu kewajiban melainkan amanah dari Allah SWT (AsySyura ayat 49-50). Tanggung jawab ibu bapak terhadap anak-anak sangat besar sekali. Amanah ersebut bermula sejak dari awal, mulai sebelum anak itu dilahirkan sampai dewasa.ermasuk dalam amanah ini ialah untuk menamakan anak-anak dengan nama-nama yng baik, menguruskan keperluannya, menjaganya daripada sesuatu yangmerusakkannya dan mendidik jasmani, rohani dan akalnya agar mampu mandirimenghadapi hidup dan memikul tanggung jawabnya. Mengasuh dan merawat anak ialah mendidik, membimbing dan mmeliharanya, mengurus makanan, minuman, pakaian, kebersihannya, atau pada segala

\footnotetext{
${ }^{22}$ Ibu Nyai Hj. Umy Salamah, Op. Cit.,
} 
perkara yang seharusnya diperlukan, sampai batas bilamana si anak telah mampu melaksanakan keperluannya. $^{23}$

Dalah hidup berumah tangga juga perlu tercipta suasana pendidikan Islam, baik itu diperoleh sebelum menikah atau setelahnya. Pendidikan di sini tidak berarti pendidikan formal semata, tetapi lebih mengarah kepada pemahaman falsafah hidup berumah tangga yang didasarkan kepada iman yang kokoh, ketakwaan serta akhlak terpuji. Karena itu, suami istri hendaknya terus mengembangkan keahlian dan keterampilan yang menunjang kesuksesan baik dalam bidang materil maupun moril. Selanjutnya adalah, tugas mendidik anak yang harus diemban oleh suami dan istri. Pendidikan anak ini penting lantaran masa depan anak mereka tergantung kepada pendidikan yang diberikan orang tua kepada anaknya sejak dini, sehingga dikatakan bahwa pendidikan adalah investasi untuk masa depan. ${ }^{24}$

\section{Pengambilan Keputusan Dalam Mengikuti Progam KB}

Dalam mengikuti progam KB haruslah ada sebuah pengambilan kesepakatan antara suami dan istri. Dari hasil wawancara yang peneliti lakukan di saat penelitian, mayoritas keluarga pesantren PP. Bahrul Ulum Tambakberas Jombang dalam pengambilan keputusan mengikuti progam KB adalah dengan bermusyawarah antara suami dan istri. Di bawah ini adalah hasil wawancara peneliti:

Di saat peneliti menanyakan pengambilan keputusan dalam mengikuti progam KB kepada ibu nyai Hj. Umi Salamah. Beliau menjawab: "Bagi saya izin suami cukup jadi saya bicara dengan suami". ${ }^{25}$ Peneliti juga menanyakan hal ini kepada bapak KH. Yahya Husnan. Beliau menjawab: "Ya bermusyawarah dengan anu (itu) beberapa pertimbanganpertimbangan, pertimbangan orang berdua, pertimbangan-pertimbangan dampak positifenegatife (positif-negatifnya) ". ${ }^{26}$

Dari keluarga bapak KH. Muhammad Iddris Djamaluddin dan ibu nyai $\mathrm{Hj}$. Muhimmatul Falasifah. Di saat peneliti menanyakan pengambilan keputusan beliau dalam mengikuti pogam KB. Ibu nyai Fasifah manjawab: "Di izini sama suami Cuma itu tujuannya itu untuk penjarangan jadi di izini suami cuma karena untuk penjarangan jarak kelahiran". ${ }^{27}$ Sedangkan suaminya yaitu bapak KH. Iddris Djamaluddin menjawab: "Ya kita tetap

\footnotetext{
23 "Institusi Keluarga Dalam Islam", http://www.geocities.com/farouq1965/TPSM/1i.htm, (diakses pada 08 Mei 2008). 4.1-4.3.

${ }^{24}$ Dedi Juneadi, Op. Cit., 179-180.

${ }^{25}$ Ibu Nyai Umy Salamah, Op. Cit.,

${ }^{26}$ Bapak KH. Yahya Husnan, Op. Cit.,

${ }^{27}$ Ibu Nyai Hj. Muhimmatul Falasifah, Op. Cit.,
} 
rembukan (musyawarah), sambil juga mendengarkan masukan-masukkan yang menjadi satu prinsip bagi saya, lah seperti itu". ${ }^{28}$

Dari keluarga bapak KH. Hasyim Yusuf dan ibu nyai Hj. Lathifah Hidayati. Pada saat peneliti menanyakan pengambilan keputusan beliau dalam mengikuti pogam KB. Ibu nyai Lathifah manjawab: "Yo rembukan, yo mesti to mbak ya namanya istri yo wes pakek izinnya suami dulu". ${ }^{29}$ ("Ya musayawarah ya pastinya

mbak ya namanya istri ya harus memakai izinnya suami dulu"). Sedangkan suaminya yaitu bapak KH. Hayim Yusuf menjawab: "Atas dasar musyawarah piye (apa) enaknya gimana". 30

Dari keluarga bapak Drs. KH. Abdul Choliq Hasan M. Hi dan ibu nyai Hj. Bashirotul Hidayah S. Ag. Saat peneliti menanyakan pengambilan keputusan beliau dalam mengikuti pogam KB. Ibu nyai $\mathrm{Hj}$. Hidayah manjawab: "Ya Izin suami mbak". ${ }^{31}$ Sedangkan suaminya tidak dapat di interviw karena terdapat kesibukkan yang sangat padat. sehingga beliau tidak dapat untuk di interviw. Dari keluarga bapak KH. Nashir Abd Fattah dan ibu nyai Hj. Ummu Salmah. Di saat peneliti menanyakan pengambilan keputusan beliau dalam mengikuti pogam KB. Ibu nyai $\mathrm{Hj}$. Salmah manjawab: "Ya berdua bermusyawarah". 32 Selanjutnya suami beliau yaitu bapak KH. Nashir Abd Fattah sulit ditemui karena terdapat kesibukkan di luar rumah maka beliau tidak dapat di interviw. Dari keluarga bapak KH. Irfan Sholeh S. Pd dan ibu nyai Dra. Hj. Siti Fatihah. Di saat peneliti menanyakan pengambilan keputusan beliau dalam mengikuti pogam KB. Ibu nyai Fatihah manjawab: "Saling mendukung antara suami istri". ${ }^{33}$ Sedangkan suami beliau yaitu bapak KH. Irfan Sholeh S. Pd pada saat penulis ingin mewawancarai beliau ternyata beliau tidak dapat diwawancarai karena belia sedang sibuk dalam mengurusi pendaftaran CALEG beliau dalam PEMILU tahun 2009 dan juga beliau terdapat kesibukkan di luar rumah seperti mengisi pengajian di luar daerah.

Dalam mengikuti dan melakukan progam KB haruslah ada sebuah pengambilan kesepakatan antara suami dan istri. Dari hasil penelitian yang peneliti lakukan, mayoritas keluarga pesantren PP. Bahrul Ulum Tambakberas Jombang dalam pengambilan keputusan mengikuti progam KB adalah dengan bermusyawarah antara suami dan istri. Hal ini dapat dikatakan bahwa beberapa keluarga tersebut ternyata terdapat keterbukaan dan komunikasi antara suami dan istri dalam hal mengikuti progam KB.

\footnotetext{
${ }^{28}$ Bapak Kh. Iddris Djamaluddin, Op Cit.,

${ }^{29}$ Ibu Nyai Hj. Lathifah Hidayati, Op. Cit.

${ }^{30}$ Bapak KH. Hasyim Yusuf, Op. Cit.,

${ }^{31}$ Ibu Nyai Hj. Bashirotul Hidayah, Op, Cit.,

${ }^{32}$ Ibu Nyai Hj. Ummu Salmah, Op, Cit.,

${ }^{33}$ Ibu Nyai Hj. Siti fatihah, Op. Cit.,
} 
Seperti pada pembahasan sebelumnya, adanya musyawarah dalam keluarga menandakan bahwa ada komunikasi, interaksi, dan kerjasama antar anggota keluarga. Tiga bentuk dari akar kata Musyawarah dalam Al-Qur'an dalam tiga ayat. Yang pertama merupakan perintah kepada Nabi Muhammad SAW. Agar tetap memusyawarahkan urusan masyarakat kepada anggota masyarakat (QS. Ali Imran [3]: 159). Yang kedua pujian kepada orang-orang mukmin yang selalu memusyawarahkan urusan mereka (QS. Asy-Syura [42]: 38). Dan yang ketiga menyangkut musyawarah antara suami-istri (QS. Al-Baqarah [2]: 233). Musyawarah adalah membahas bersama dengan maksud mencapai keputusan dan penyelesaian bersama dalam bentuk yang sebaik-baiknya. Musayawarah bukan untuk mencari kemenangan, tetapi untuk mencari yang terbaik. ${ }^{34}$ Al-Qur'an pun memerintahkan kedua pasangan untuk memusyawarahkan persoalan-persoalan menyangkut rencana masa depan dan anak-anak mereka. ${ }^{35}$ Seperti pada penjelasan Firman Allah dalam

Surat Al-Baqarah ayat 233.

Berhubungan dengan ayat tersebut di atas, menjelaskan bahwa perlu musyawarah antara suami-istri dan adanya persetujuan dari keduanya jika ingin menyapih anaknya lebih cepat dari dua tahun. Dan ini berarti pengaturan atau penjarangan kahamilan itu mutlak diperlukan musyawarah antara suami-istri dan adanya persetujuan dari mereka yang bersangkutan.

Musyawarah artinya segala aspek kehidupan dalam rumah tangga harus diputuskan diselesaikan berdasarkan hasil musyawarah antara suami dan istri dan kalau dibutuhkan juga melibatkan seluruh anggota keluarga yakni suami, istri dan nak-anak. Kehidupan dalam rumah tangga juga memerlukan adanya demokrasi, demokrasi disini diperlukan karena antara suami istri harus saling terbuka untuk menerima pandangan dan pendapat pasangan. Demikian juga antara orang tua dan anak harus menciptakan suasana yang saling menghargai, menghormati dan menerima pandangan dan pendapat anggota keluarga. Sebagai relisasi dan sikap demokratis, suami istri harus menciptakan suasana yang kondusif (mendukung) untuk memunculkan rasa persahabatan di antara anggota keluarga dalam berbagi suka dan duka, dan merasa mempunyai kedudukan yang sejajar dan bermitra, tidak ada pihak yang merasa lebih hebat dan lebih tinggi kedudukannya, tidak ada pihak yang mendominasi dan menguasai. Demikian juga sebaliknya. Dengan musyawarah dan demokrasi

\footnotetext{
${ }^{34}$ M. Quraish Shihab, Pengantin Al-Qur'an Kalung Permata Buat Anak-anakku, (Jakarta: Lentera Hati, 2007), $140-141$

${ }^{35}$ Ibid., 151-152.
} 
ini diharapkan akan memunculkan kondisi yang saling melengkapi dan saling mengisi antara satu dengan yang lainnya.

Musyawarah dan demokrasi ini dapat diwujudkan dalam bentuk: memutuskan masalah-masalah yang berhubungan dengan reproduksi, jumlah dan pendidikan anak dan keturunan, menentukan tempat tinggal (rumah), memutuskan masalah-masalah yang dihadapi dalam kehidupan rumah tangga, dan pembagian tugas-tugas rumah tangga ataupun yang lainlainnya.

Masalah-masalah yang berhubungan dengan reproduksi, jumlah, dan pendidikan anak dan keturunan, apakah pasangan akan ber-KB atau tidak, kalau memang akan ber-KB, jenis KB apa yang akan digunakan, harus dimusyawarahkan antara suami dan istri. Demikian juga jumlah anak yang akan diinginkan dalam keluarga, bagaimana pendidikannya, apakah ingin dididik di sekolah agama lebih dahulu kemudian masuk pendidikan umum, atau sebaliknya diawali dengan pendidikan lebih dahulu baru masuk pendidikan agama, atau keduanya secara bersama. Apakah akan mempunyai anak 5 atau 6 atau cukup 2 saja, yang penting kualitas, dan sejenisnya, sudah seharusnya diputuskan secara bersama dengan musyawarah. ${ }^{36}$

\section{Implikasi KB Dalam Membentuk Keluarga Sakinah}

KB pada umumnya terdapat beberapa implikasi bagi seseorang yang mengikuti progam tersebut. Implikasi tersebut dapat berdampak dari segi kesehatan, pendidikan, ekonomi, psikologis dan agama. Dari hasil penelitian dilapangan ternyata KB juga mempunyai dampak positif dan negatif dalam mempengaruhi pembentukan keluarga sakinah. Di bawah ini adalah hasil wawancara peneliti, diantaranya adalah:

\section{a. Implikasi Positif}

Di bawah ini adalah hasil wawancara peneliti dengan beberapa keluarga pesantren PP. Bahrul ulum Tambakberas Jombang mengenai implikasi positif KB dalam membentuk keluarga sakinah dari segi kesehatan:

Pasangan bapak KH. Yahya Husnan dan ibu nyai Hj. Umi Salamah. Ketika peneliti menanyakan tentang implikasi KB terhadap pembentukan keluarga sakinah di keluarga bapak KH. Yahya Husnan dan ibu nyai Hj. Umi Salamah. Bapak KH. Yahya menjawab:

"Manfaate yo iku mau yo podo ae manfaate, manfaate yo kemudian gak terlalu seringsering melahirkan, soale melahirkan sendiri yo banyak resiko to orang melahirkan, kayok wes enggak kuat maneng gawe melahirkan soale usiane wes di

\footnotetext{
${ }^{36}$ Khoiruddin Nasutioan, Membentuk Keluarga Sakinah (Yogyakarta: PSW IAIN Sunan Kalijaga, 2002), 32-35.
} 
atas 35 tahun lah seumpanya melahirkan maneng iku engkok berbahaya pada anaknya, anak e iso meninggal ibu e juga iso meninggal. dengan adanya kita atur melahirkannya yo dengan progam KB tadi". 37

Dengan adanya kita atur melahirkannya ya dengan progam KB tadi ”. Peneliti juga menanyakan tentang implikasi KB terhadap pembentukan keluarga sakinah di keluarga bapak KH. Muhammad Iddris Djamaluddin dan ibu nyai Hj Muhimmatul Falasifah. Ibu nyai Hj. Falasifah menjawab:

"Lek manfaatnya jelas gak hamil, kalau madhorotnya itu gak sebegitu anu, karena yang memang 1 bulan (jenis KB yaitu pil KB) sekali itukan baik ketimbang seng 3 bulan sekali, 3 bulan sekalikan gemuk terus kadang ya gak haid belas, kalau 1 bulan sekali itu haidnya teratur terus gak gemuk". ${ }^{38}$

Pasangan bapak Drs. KH. Abdul Choliq Hasan M. Hi dan ibu nyai Hj. Bashirotul Hidayah S. Ag. Selanjutnya peneliti juga menanyakan tentang implikasi KB terhadap pembentukan keluarga sakinah kepada beliau. Ibu nyai Hj. Bashiro menjawab: "KB memberi waktu bagi organ reproduksi ibu untuk beristirahat sejenak disamping kesibukannya membesarkan putra-putrinya membutuhkan energi yang prima. Mengikuti KB asal yang cocok (tentu dengan konsultasi ahlinya) berguna bagi kehidupan bayinya karena ia akan memperoleh cukup ASI selama 2 tahun". 39

Pasangan bapak KH. Nashir Abd Fattah dan ibu nyai Hj. Ummu Salmah. Selanjutnya peneliti juga menanyakan tentang implikasi KB terhadap pembentukan keluarga sakinah kepada beliau. Ibu nyai $\mathrm{Hj}$. Salmah menjawab:

"Gak (tidak) ada biasa-biasa aja, ya dampak positifnya apa ya, ya dampak positifnya mungkin bisa lebih mempersiapkan eh apa kelahiran anak yang kedua. Dampak negatif gak (tidak), kalau saya tambah gendut itu tidak karena suntik KB. Karena saya kebanyakan orang dan menurut medis itukan begitu berhenti suntik KB kan biasanya langsung ada, kalau sayakan gak (tidak) sampek 2 tahun lebih belum ada lagi, berhenti sampek 2 tahun lebih belum ada saya sempat penyuburan itu yang menjadikan saya gemuk bertambah berat badannya itu ketika penyuburun". ${ }^{40}$

Menurut hasil wawancara di atas menyebutkan bahwa implikasi positif KB dari segi kesehatan yaitu tidak membuat hamil dan tidak terlalu sering-sering melahirkan, karena perempuan yang sering melahirkan dan sudah punya lebih dari empat anak dihadang bahaya kematian akibat pendarahan hebat dan macam-macam kelainan lain, apabila terus saja hamil dan bersalin lagi. KB juga memberi waktu bagi organ reproduksi ibu untuk beristirahat

\footnotetext{
${ }^{37}$ Bapak KH. Yahya Husnan, Op. Cit.,

${ }^{38}$ Ibu Nyai Hj. Muhimmatul Falasifah, Op. Cit.,

${ }^{39}$ Ibu Nyai Hj. Bashirotul Hidayah, Op Cit.,

${ }^{40}$ Ibu Nyai Hj. Ummu Salmah, Op, Cit.,
} 
sejenak disamping kesibukannya membesarkan putra-putrinya membutuhkan energi yang prima.

Pencegahan kehamilan karena keterpaksaan, seperti tidak bisa melahirkan secara alami sehingga harus melalui operasi untuk mengeluarkan bayinya, maka pencegahan kehamilan boleh dilakukan. Adapun dengan penggunaan alat, seperti pil dan yang serupa dengannya, untuk menunda kahamilan dalam masa tertentu demi kemaslahatan istri, seperti karena kondisi fisiknya yang sangat lemah sehingga tidak kuat untuk hamil secara berturutturut, bahkan bisa membahayakan maka tidak berdosa. Dalam kondisi atau masa tertentu penundaan harus dilakukan sampai teratur bahkan mencegahnya sama sekali jika dipastikan kehamilannya membahayakan.

Mengikuti KB asal yang cocok tentu dengan konsultasi ahlinya berguna bagi kehidupan bayinya karena ia akan memperoleh cukup ASI selama 2 tahun. Di samping itu juga bisa lebih mempersiapkan kelahiran anak yang kedua. Telah dijelaskan pada pembahasan sebelumnya, bahwa melaksanakan KB dengan motivasi yang hanya bersifat pribadi, misalnya ber-KB untuk menjaga kesehatan badan ibu dan anak, hukumnya boleh saja. ${ }^{41}$ Seperti yang sudah dijelaskan didalam Firman Allah dalam Surat Al-Baqarah ayat 233, yang menjelaskan bahwa para ibu hendaklah menyusui anak-anaknya selama dua tahun penuh dan tidak dibenarkan seorang ibu menderita karena anaknya, dengan demikian pula ayahnya dan ahli warisnya.

Sedangkan implikasi positif KB yang lain adalah seperti manfaat menyusui bermanfaat bagi proses pembentukan kecerdasan otak anak dan kesehatan karena mengandung zat kekebalan terhadap penyakit, bersih dan mudah diberikan secara cepat serta tidak membeli. ASI bukan saja bermanfaat bagi bayi tetapi juga bagi ibunya menyangkut kesehatan reproduksi ibu yaitu membuat ibu sehat secara fisik, mental dan sosial secara menyeluruh menyangkut sistem, fungsi dan proses reproduksi dan bukan bebas dari kecacatan atau penyakit, dengan menyusui akan memulihkan kesehatan ibu mempelancarkan pencernaan dalam perut dan terhindar dari penyakit kanker payudara serta akan mencegah kehamilan selama masih menyusui. Memberikan ASI selama dua tahun merupakan proses pengaturan kelahiran atau keluarga berencana, dengan pengaturan kelahiran di sini dapat merawat anak-anak mereka dengan baik. Disamping seorang anak juga membutuhkan perhatian dan kasih sayang orang tua. Pengaturan kelahiran ini juga orang tua dapat lebih

\footnotetext{
${ }^{41}$ Masjfuk Zuhdi, Op. Cit., 61.
} 
mendekatkan diri ke semua anak-anaknya karena kedekatan hubungan orang tua dan anak akan mempengaruhi pembentukan k eluarga sakinah.

Manfaat menyusui selain dari segi kesehatan juga menimbulkan rasa kasih sayang dalam keluarga dan anak menjadi sehat sehingga dapat terbentuk keluarga sakinah, dalam program KB Nasional disebut keluarga berkualitas yaitu keluarga yang sejahtera, sehat, maju, mandiri, berwawasan ke depan, bertanggung jawab, harmonis dan bertaqwa kepada Tuhan Yang Maha Esa dengan melasanakan fungsi keluarga. ${ }^{42}$ Cinta kasih sayang dalam keluarga merupakan modal dasar kehidupan keluarga muslim dengan tidak boleh membelokkan tujuan hidup akhirat yang abadi.

Hidup sejahtera merupakan faktor yang sangat penting bagi terbentuknya keluarga sakinah, sejahtera dalam arti lahir batin yaitu terpenuhinya kebutuhan hidup baik jasmani dan rohani. Untuk dapat hidup sejahtera, ada beberapa kebutuhan pokok hidup manusia yang harus dipenuhi salah satunya yaitu terpenuhinya kebutuhan kesehatan. Maka dari itu dengan manyusui anak dapat terindar dari penyakit. Apabila anak, ibu dan anggota keluarga semuanya sehat tentu akan dapat mempengaruhi pembentukan keluarga sakinah. Tidak mungkin suatu keluarga sejahtera dapat terwujud jika anggota keluarga itu tidak sehat. Apa artinya kekayaan yang banyak bila tidak bisa menikmati lantaran si empunya harta itu sakit. Agama Islam menganjurkan kepada umatnya untuk selalu memelihara kesehatan dengan sebaik-baiknya.

Maka tidak diragukan lagi, bahwa implikasi positif KB dari segi kesehatan termasuk perkara yang menjadi salah satu sarana pendukung dalam membentuk keluarga sakinah adalah kesehatan lahir dan batin. Kesehatan lahir merupakan sarana pendukung yang vital dalam beribadah kepada Allah SWT. karena itulah Islam sebagai agama yang kamil (sempurna) dari segala sisinya, telah menaruh perhatian besar terhadap masalah kesehatan. Pengetahuan tentang konsep-konsep global dan terperinci dalam masalah kesehatan, amatlah penting artinya bagi kehidupan kaum muslimin secara umum, dan pasangan suami istri secara khusus. ${ }^{43}$ Suami istri harus memelihara kesehatan lahir dan batin agar dapat melaksanakan tugas masing-masing dengan baik.

Psikologis juga salah satu implikasi KB dalam pembentukan keluarga sakinah. Di bawah ini adalah hasil wawancara peneliti dengan keluarga pesantern PP. Bahrul ulum Tambakberas Jombang mengenai implikasi positif KB dalam membentuk keluarga sakinah 
dari segi psikologisnya: Pasangan bapak KH. Yahya Husnan dan Ibu nyai Hj. Umi Salamah. Ibu nyai Hj. Umi menjawab:

"Jadi saya kalau kondisi fisik kurang fit itukan membawa dampak ya dalam model pendidikan, wes emboh ojok takon aku, aku wes pegel seperti itu dan kondisi hamil misalnya lek hamil terus wes aku gak bisa banyangkan lagi kalau terlalu dekat jaraknya seperti tipe saya loh yah kalau sampean tanya-tanya kesaya mungkin sampean tanya kepada orang lain jawabannya berbeda itu kalau menurut saya jawabannya seperti itu". 44

Dampak positif dari segi psikologis KB terhadap pembentukan keluarga sakinah yaitu apabila KB yang benar dan sesuai tentu akan berdampak positif bagi pasangan suami-istri, terutama istri. Karena disamping ia tetap bisa maksimal merawat buah hatinya dan dapat membagi kasih sayang dengan merata ke semua anak-anaknya, sehingga keharmonisan tetap terjaga. sisi lain positif KB dilihat dari segi psikologisnya wanita yang sedang hamil kadang membuat kondisi emosialnya kurang stabil lantaran capek, apabila orang tuanya selalu emosi dikhawatirkan akan membawa dampak kepada psikologis anak-anaknya yang lain. Maka dari sinilah peran KB diperlukan untuk dapat membangun dan mewujudkan keluarga sakinah.

Salah satu misi membangun dan mewujudkan keluarga sakinah yaitu menjalin hubungan cinta insani dan ruhani, Menjalin kasih sayang. Dalam kehidupankeluarga, anakanak membutuhkan dialog yang penuh dengan pendekatan manusiawi dan kasih sayang. anak-anak membutuhkan perhatian, pemeliharaan, perlindungan, pengawasan dan bimbingan. ${ }^{45}$ Hal ini selaras dengan pendapat Dedi Junaedi di dalam bukunya yang berjudul keluarga sakinah pembinaan dan pelestariannya, mengatakan bahwa sikap keibuan dan kebapakan adalah dua kasih sayang tinggi nilainya dan bersumber dari kedua orang tua yang harus diberikan kepada buah hati mereka, di samping harus mengemban berbagai kesulitan dan pengorbanan. Orang tua harus menutup kekerasannya dengan sampul kasih sayang dan kelembutan. Dengan kasih sayang pertumbuhan kepribadian anak menjadi sempurna dan dapat melaksanakan risalahnya dalam kehidupan dengan sebaik mungkin. ${ }^{46}$

Kasih sayang orang tua terhadap anak harus dengan kadar yang masuk akal dan bijak, yakni kasih sayang yang bercampur kekerasan, tidak berlebihan dan tidak lalai, tidak membiarkan anak bermain semaunya dan bergaul dengan orang yang diinginkan tanpa ada

\footnotetext{
${ }^{44}$ Ibu Nyai Hj. Umi Salamah,Op, Cit.,

${ }^{45}$ Aidil Amien, "Persiapan Nikah Dan Menjaga Keharmonisan Pasca Nikah",

http://ilovequ.wordpress.com/2008/01/01/menikah-sebuah-keniscayaan-menuju-ummatpilihan/, (diakses pada 18 Agustus 2008).

${ }^{46}$ Dedi Juneadi, Op. Cit., 147-148.
} 
pengawasan. Hal ini lantaran anak kecil apabila tidak mendapat kasih sayang ia akan berprilaku menyimpang dan jika diberikan kasih sayang yang berlebihan juga akan sebaliknya. Seperti penjelasan pada pembahasan sebelumnya bahwa orang tua harus memperlakukan semua anak-anaknya dengan adil, orang tua yang memiliki anak lebih dari satu, ia juga berkewajiban untuk berbuat adil terhadap anak-anaknya itu. Orang tua tidak boleh membedakan yang satu dengan yang lain, yang laki-laki dengan yang wanita, baik dalam kasih sayang yang bersifat moril maupun dalam hal-hal yang bersifat materil. Sikap adil ini bukan berarti memberinya porsi yang sama, tetapi menempatkan anak-anak sesuai dengan kebutuhannya. Sikap ini perlu diperhatikan sebab ketidakadilan akan menjadikan sebagian anak merasa diabaikan yang dikhawatirkan kelak tidak memiliki rasa hormat dan kasih sayang terhadap orang tua. ${ }^{47}$

Dari segi ekonominya hanya terdapat dua keluarga saja yang mempunyai implikasi tersebut di antranya adalah pasangan bapak KH. Yahya Husnan dan ibu nyai Hj. Umi Salamah. Bapak KH. Yahya menjawab dari segi ekonominya yaitu:

"Resiko biaya yo kesehatan iku maeng yo merupakan resiko dengan adanya kita atur melahirkannya yo dengan progam KB tadi, kita bisa lebih rilex gak terlalu opo, gak terlalu memikirkan sering-sering memikirkan ekonomi biaya untukmelahirkan dan kehidupan". 48

Pasangan bapak KH. Nashir Abd Fattah dan ibu nyai Hj. Ummu Salmah. Ibu nyai Hj. Salmah menjawab:

"Gak (tidak) ada biasa-biasa aja, ya dampak positifnya apa ya, ya dampak positifnya mungkin bisa lebih mempersiapkan eh apa kelahiran anak yang kedua, kemudian lebih fokus ke apa eh anak yang pertama kemudian lebih fokus karena ini anak pertama dengan anak kedua otomatiskan tidak hanya kita tidak berpikir hanya bagaimana mempersiapkan anak yang kedua dan seterusnya inikan juga berkaitan dengan mungkin itu apa banyak orang yang ikut berkaitan dengan ekonomi juga kan". 49

Menurut hasil penelitian ini dilihat dari segi ekonomi, dengan mengikuti KB dapat memberikan implikasi positif kepada keluarga dalam mewujudkan keluarga sakinah, seseorang dapat lebih santai dalam memikirkan hal yang berkaitan dengan masalah ekonomi. Hal ini seperti ungkapan bapak KH. Yahya Husnan dan ibu nyai Hj. Ummu Salmah.

Keluarga sakinah adalah keluarga yang terlahir dari usaha keras pasangan suami istri dalam memenuhi semua kewajiban, salah satunya adalah kebutuhan ekonomi. Kepala keluarga wajib mencukupi kebutuhan nafkah istri dan anak-anaknya dengan berbagai usaha yang halal. Kebutuhan ekonomi adalah kebutuhan asasi seperti sandang, papan dan pangan,

\footnotetext{
${ }^{47}$ Dedi Junaedi, Op., Cit. 154.

${ }^{48}$ Bapak KH. Yahya Husnan, Op, Cit.

${ }^{49}$ Ibu Nyai Hj. Ummu Salmah, Op, Cit.,
} 
serta kebutuhan dharuri seperti pendidikan, kesehatan, keamanan. Kecukupan sandang, pangan, dan papan.

Kecukupan sandang sangat penting sebab manusia sebagai hamba Allah dan sebagai makhluk sosial yang beradab memerlukan sandang sebagai penutup aurat untuk beribadah kepada Allah SWT. Suami istri juga memerlukan hidup yang layak dalam pergaulan masyarakat sesuai dengan tingkat sosialnya. Pangan juga tidak kalah penting sebab cinta tanpa beras akan menciptakan malam yang tidak berkesan dan pagi hari perut keroncongan. Oleh sebab itu, sebelum menikah hendaknya sudah mempunyai lapangan kerja yang dapat menghasilkan uang dan setelah menikahpun suami istri harus bekerja keras dan memohon pertolongan Allah SWT lewat doa dan ibadah yang dilaksanakan setiap hari. Selain itu, berkeluarga juga memerlukan papan sebagai tempat tinggal dan tempat usaha mencari nafkah hidupnya. Jangan sampai setelah menikah suami istri numpang terus menerus pada orang tua, sebab hal ini akan menimbulkan berbagai masalah kehidupan berumah tangga. Karena itu, usaha dan kerja keraslah demi rumah tangga yang mandiri dan bebas dari campur tangan pihak ketiga. Memang uang bukan segala-galanya, tetapi dalam kenyataan hidup di dunia ini hampir segalagalanya pakai uang. ${ }^{50}$

Seseorang harus mempunyai keterampilan untuk dapat menghasilkan dan memenuhi kebutuhan ekonomi rumah tangga sehari-hari. Tugas suami adalah sebagai pencari nafkah sedangkan istri sebagai ibu rumah tangga berperan mangatur pendapatan dengan terampil. Apabila pendapatan itu tidak diatur dengan baik dikhawatirkan akan membawa kepada pemborosan. Maka dari sinilah diperlukan adanya kestabilan ekonomi dalam kehidupan berkeluarga. Kestabilan ekonomi merupakan salah satu penunjang terwujudnya keluarga sakinah. Kondisi keuangan sebuah keluarga bisa dikatakan stabil apabila terdapat keseimbangan antara pemasukan dan pengeluaran. Tidak sedikit kasus kegagalan menciptakan keluarga sakinah, dan bahkan manjadi retak dan berantakan, terjadi karena keadaan ekonomi keluarga yang kurang stabil. Bahkan persoalan ekonomi juga sering mempengaruhi kadar keimanan seseorang. Dalam hal ini, Rasulullah SAW, pernah mengatakan: "Hampir saja kefakiran itu menjadi kafir." Dan beliau juga mengajarkan doa: "Ya Allah kami berlindung kepadaMu dan kefakiran dan kekufuran".

Oleh karena itu, dengan mengikuti program KB maka anggota keluarga terutama kepala rumah tangga berharap ekonomi keluarga terpenuhi, karena dengan mengikuti KB maka kelahiran anak akan teratur dan kekayaan yang dimiliki keluarga tidak habis begitu saja

${ }^{50}$ Dedi Juneadi, Op. Cit., 178-179. 
untuk masalah kelahiran anak dan mencukupi kebutuhan anak yang banyak. Jadi, ketika kekayaan dihabiskan untuk enam orang anak, karena mengikuti KB maka bisa saja hanya untuk dua atau tiga orang anak saja. Ketika ekonomi keluarga dapat memenuhi segala kebutuhan anggota keluarga dengan cukup maka akan tercipta keluarga yang bahagia atau kesakinahan keluarga akan tercapai.

Dari segi pendidikan ada beberapa keluarga saja yang mendapat implikasi positif dalam pembentukan keluarga sakinah di antranya yaitu: pasangan bapak KH. Yahya Husnan dan ibu nyai Hj. Umi Salamah. Bapak KH. Yahya menjawab yaitu: "Pendidikannya juga bisa lebih banyak terkontrol karena ibu gak (tidak) terlalu sering melahirkan". 51

Pasangan bapak KH. Muhammad Iddris Djamaluddin dan Ibu nyai $\mathrm{Hj}$. Muhimmatul Falasifah. Bapak KH. Iddris Djamaluddin menjawab: "Sepanjang hal itu di sepakati oleh mereka berdua saya pikir tidak ada negatifnya, malah ada sisi positifnya kalau memang Allah menjadikan keluarga itu adalah keluarga yang bukan keluarga yang memiliki lingkungan yang baik terhadap anak-anaknya mungkin juga lebih baik dia membatasi keturunan". ${ }^{2}$

Pasangan bapak KH. Hasyim Yusuf dan ibu nyai Hj. Lathifah Hidayati. Bapak KH. Hasyim menjawab: "Kalau memang dampak positif memang kita bisa mendidik anak dengan leluasa, KB yang dimaksud disini itu KB untuk jarak itu loh jadi kalau untuk mematikan anak ya dampaknya ya luar biasa negatifnya". 53

Pasangan bapak Drs. KH. Abdul Choliq Hasan M. Hi dan ibu nyai Hj. Bashirotul Hidayah S. Ag. Ibu nyai Hj. Bashiro menjawab:

"KB yang benar dan sesuai tentu akan berdampak positif bagi pasangan suamiistri, terutama istri. Karena disamping ia tetap bisa maksimal merawat buah hatinya, iapun tetap bisa optimal menjaga kesehatan tubuh dan staminanya sehingga keharmonisan terjaga. Meskipun bukan ini satu-satunya alasan hidup harmonis. Yang utama adalah pondasi agama dan segala persoalan terdialogkan dengan baik diantara suami-istri. Harmonis atau disharmonis dalam rumah tangga tidak semata-mata karena faktor KB. segala sesuatu yang terdialogkan dengan bijaksana tentu akan membawa dampak positif. Namun sekali lagi repoduksi perempuan membutuhkan waktu untuk sekedar beristirahat guna berproduksi kembali agar terjaga kesehatan yang diharapkan". ${ }^{54}$

Pasangan bapak KH. Irfan Sholeh S. Pd dan ibu nyai Dra. Hj. Siti Fatihah. Ibu nyai Hj. Fatihah menjawab: "Dampak positif jelas karena kita gak (tidak) terlalu dibebankan dengan ngurusi anak yang terlalu banyak". 55

\footnotetext{
${ }^{51}$ Bapak KH. Yahya Husnan, Op, Cit.,

${ }^{52}$ Bapak KH. Iddris Djamaluddin, Op, Cit.,

${ }^{53}$ Bapak KH. Hasyim Yusuf, Op, Cit.

${ }^{54}$ Ibu Nyai Hj. Bashirotul Hidayah, Op, Cit.,

${ }^{55}$ Ibu Nyai Dra. Hj. Siti Fatihah, Op, Cit.,
} 
Implikasi positif KB dalam membentuk keluarga sakinah dari sisi pendidikan seperti yang diungkapkan di atas yaitu membuat pendidikan anak-anak dapat menjadi lebih banyak terkontrol karena ibu tidak terlalu sering melahirkan, sehingga dapat mendidik anak dengan baik dan leluasa. Salah satu kewajiban orang tua adalah memikul kewajiban untuk mengasuh, mendidik dan memelihara anak-anak mereka, baik mengenai pertumbuhan jasmani, rohani maupun kecerdasannya dan pendidikan agamanya. ${ }^{56}$ Pemenuhan pelayanan pendidikan bagi anak-anak adalah mutlak harus dilakukan dalam rangka mewujudkan keluarga sakinah. Pendidikan yang diberikan orang tualah yang akan menentukan terhadap kepribadian anakanak setelah mereka dewasa. Setiap orang tua dalam rangka mendidik anak-anaknya bertanggung jawab meluruskan fitrah dan nilai-nilai kemanusiaan anaknya yang asli dan murni sebagai pembawaan setiap manusia sejak lahir ke dunia.

Kondisi anak yang masih suci bersih, memiliki daya tangkap yang lebih kuat, seandainya pada tahap ini ia tidak dididik dengan baik atau mendapat pendidikan yang tidak memiliki arah dan tujuan, niscaya anak itu akan terbelakang dan bodoh, lemah pandangan dan berprilaku menyimpang. Karena itu, pendidikan anak adalah kewajiban orang tua, di mana keluarga adalah lingkungan yang paling awal dan sangat mempengaruhi perkembangan seorang anak. Oleh sebab itu, keluarga yang harmonis, sakinah, dan didasari nilai-nilai agama harus benar-banar diciptakan dan diusahakan sebaik mungkin. ${ }^{57}$

Pendidikan yang paling baik dan yang memberikan suatu response positip terhadap berbagai perkembangan kehidupan, seperti perkembangan ilmu pengetahuan, teknologi, kebudayaan dan lain-lain tiada lain adalah pendidikan Islam sebagai satu-satunya peraturan Ilahi yang mengatur tata kehidupan manusia yang sempurna ajarannya. Memberikan pendidikan terhadap anak-anak masih kecil, karena pendidikan yang dimulai sejak kecil akan memberikan bekas yang kuat terhadap pembentukan watak serta kepribadian si anak setelah dewasa. Seperti penjelasan di atas, orang tua juga berkewajiban mendidik anakanaknya sebagai bekal mengarungi kehidupan dunia dan akhirat, sehingga menjadi manusia hamba Allah yang diharapkan. Di antara kewajiban agama yang harus dilaksanakan oleh kepala rumah tangga adalah mendidik keluarga agar selamat dari siksa Allah, Tanggung jawab orang tua terhadap pendidikan anak-anaknya ini sesuai dengan firman Allah dalam surat At-Tahrim ayat 6 .

Ayat di atas menjadi dasar hukum kewajiban mendidik keluarga agar setiap anggota keluarga mampu menebarkan kebaikan dan mencegah kemungkaran. Dhahhak dan Muqatil

\footnotetext{
${ }^{56}$ Slamet Abidin, Op., Cit. 158.

${ }^{57}$ Dedi Junaedi, Op., Cit. 153.
} 
berpendapat bahwa maksud ayat di atas adalah seorang muslim wajib mendidik keluarganya agar mengerti segala perintah Allah dan larangannya. Ali bin Abi Thalib berpendapat bahwa maksud ayat di atas adalah orang tua wajib memberikan pendidikan agama, bagaimana cara berbuat kebaikan, dan bagaimana bersopan-santun kepada keluarga kita. Dalam kesibukkan menjalankan tugas dan aktivitas kesehariannya, seorang kepala keluarga jangan sampai lupa meluangkan waktunya untuk mendidik keluarganya. ${ }^{58}$

Keluarga merupakan lingkungan pertama dan utama bagi anak-anak. Oleh arena itu, memberikan pendidikan kepada anak-anaknya sebagai anggota keluarga merupakan faktor yang amat penting demi perkembangan kepribadian anak-anak. Pembentukan kepribadian dimulai dengan penanaman jiwa agama. Pendidikan agama kepada anak-anak di lingkungan keluarga mempunyai makna pembentukan kepribadian, dan merupakan tanggung jawab penuh orang tua. Pendidikan agama di sini meneliputi integrasi pengenalan materi, penghayatan dan juga pengalaman. Pembinaan rumah tangga Islami akan menjadi faktor pendukung terwujudnya keluarga sakinah.

Untuk menciptakan keluarga sakinah ada beberapa aspek yang harus diperhatikan, di antaranya: Harus ada kesabaran dari orang tua dalam mendidik anaka-naknya. Selalu mengikuti perkembangan anak dan membekali mereka dengan ilmu (agama dan dunia). Menanamkan nilai-nilai moral dan agama kepada anak-anak teruatam ketika masih dalam tarap perkembangan. Pendidikan yang baik juga merupakan wujud kasih sayang orang tua kepada anak. Seluruh aspek pendidikan ini akan berjalan maksimal apabila orang tua dapat dijadikan teladan bagi anak-anaknya di samping harus berusaha secara maksimal agar setiap orang tua melakukan pekerjaan yang baik bagi keluarganya dapat melakukan seperti yang orang tua lakukan. Hal inilah yang telah dipraktekkan oleh Rasulullah SAW di tengah-tengah keluarganya.

\section{b. Implikasi Negatif}

Implikasi negatif KB dalam pembentukan keluarga sakinah apabila dilihat dari segi kesehatan, seperti yang di tuturkan oleh ibu nyai $\mathrm{Hj}$. Umi Salamah di bawah ini:

"Saya KB pil terus itu batuk jadi hormone yang di anu, jadi rupanya itu tidak kuat tubuh saya akhirnya saya batuk sampek setahun. Jadi lepas KB hilang batuknya terus maringunu saya gak berani pil lagi terus awak ku bewedah suntik saya gak berani wedi aku ketok dom iku wes wedi terus maringunu kondom akhire ngeh kondom iku yang saya pilih lah saya mosok seng harus KB yang perempuan aja yang laki-laki juga harus ikut merasakan". 59

\footnotetext{
${ }^{58}$ Muhammad Shalih Al-Munajjid, 40 Kiat Menuju Keluarga Sakinah (Yogyakarta: Pustaka Fahima, 2007), 4042.

${ }^{59}$ Ibu Nyai Hj. Umy Salamah, Op, Cit.,
} 
Saat pertanyaan ini ditanyakan kepada bapak KH. Yahya Husnan, menjawab:

"Nek negatifnya yo seng tak erui dari pihak istri itu dengan suntik itu berakibat kegemuan, terus dengan pil iku akibat kesehatannya kurang sehat iku bu Um biyen iku nganggo pel iku wes prikso nang endi-endi watuk ae, terus ketemune iku neng gone dokter Jannah Jombang iku coba anu bu tolong diberhentikan dulu pilnya, mandek yo mandek watuke, iku kesehatane terganggu". ${ }^{0}$

Hal ini pula dituturkan oleh ibu nyai $\mathrm{Hj}$. Muhimmatul Falsifah, beliau menjawab: "Cuma memang anu kemarin sempat keluar flek-flek, yang diserangkan macemmacem terus pernah juga haidnya lama 15 hari, ngeh teratur cuma ngeh gak normal kadang mek telong dino", 61

Pasangan bapak KH. Hasyim Yusuf dan ibu nyai Hj. Lathifah Hidayati. Selanjutnya peneliti juga menanyakan tentang implikasi $\mathrm{KB}$ terhadap pembentukan keluarga sakinah di keluarga bapak KH. Hasyim Yusuf dan ibu nyai Hj. Lathifah Hidayati. Ibu nyai $\mathrm{Hj}$. Lathifah menjawab: "Apalagi ketika pemasangan terjadi keputihan hebatkan selama 1 bulan itu masih hanya keputihan kalau sudah seperti suntik itukan bisa siklus haidnya kan kacau gitukan biasanyakan begitu". ${ }^{6}$

Peneliti juga menanyakan tentang implikasi KB terhadap pembentukan keluarga sakinah kepada suami ibu nyai $\mathrm{Hj}$. Lathifah. Bapak KH. Hasyim Yusuf menjawab: "Menstruasi yang mestinya segini-segini yang sudah ditentukan oleh Allah tapi ternyata acak-acakan (berantakan) akhirnya menstruasi antara haid dan istiranya atau tidaknya itu sangat sulit dibedakan itu adalah dampak negatif dari KB".63

Implikasi negatif KB juga dirasakan oleh ibu nyai Hj. Ummu Salmah, ketika beliau diinterviw. Beliau menjawab: "Ya dampak negatife (negatifnya) yang mungkin itu tidak segera hamil lagi itu mungkin". ${ }^{64}$ Kemudian ketika peneliti menanyakan tentang implikasi KB terhadap pembentukan keluarga sakinah di keluarga pesantren khususnya di keluarga bapak KH. Irfan Sholeh S. Pd dan ibu nyai Dra. Hj. Siti Fatihah. Beliau menjawab: "Kalau negatif saya rasa gak eneklah (tidak ada lah) mungkin tambah gendut karena hormonal". ${ }^{65}$

Berbagai metode tradisional dan metode modern dalam mencegah kehamilan samasama diizinkan, selama metode tersebut tidak merugikan kesehatan. Seiring dengan

\footnotetext{
${ }^{60}$ Bapak KH. Yahya Husnan, Op. Cit.,

${ }^{61}$ Ibu Nyai Hj. Muhimmatul Falasifah, Op. Cit.,

${ }^{62}$ Ibu Nyai Hj. Lathifah Hidayati, Op Cit.,

${ }^{63}$ Bapak KH. Hasyim Yusuf, Op Cit.,

${ }^{64}$ Ibu Nyai Hj. Ummu Salmah, Op, Cit.,

${ }^{65}$ Ibu Nyai Dra. Hj. Siti Fatihah, Op, Cit.,
} 
perkembangan dan kemajuan yang dicapai dan diketahui oleh umat manusia. ternyata, banyak ditemukan perangkat, cara, dan alat-alat yang serupa dengan 'azl sebagai cara untuk mencegah terjadinya kehamilan. Salah satu metode modern yaitu metoda hormonal, yang mencegah indung telur mengeluarkan sel-sel telur, mempersulit pembuahan, dan menjaga agar dinding-dinding rahim tak menyokong terjadinya kehamilan yang tak dikehendaki. Dalam metoda hormonal terdapat tiga jenis alat KB yang dapat dipilih seperti pil pengendali kehamilan yang harus diminum setiap hari. Suntikan yang diberikan setiap beberapa bulan sekali. Susuk yang biasanya dimasukkan ke dalam lengan dan tahan sampai beberapa tahun.

Metode tersebut juga mempunyai sisi negatif atau efek samping pada akseptor, seperti muntah-muntah, pusing, mual dan bertambahnya berat badan. Begitu juga dengan menggunakan alat-alat KB yang dimasukkan ke dalam rahim juga mempunyai efek samping yakni seminggu pertama, mungkin ada pendarahan kecil. Ada perempuan-perempuan pemakai spiral yang mengalami perubahan haid, menjadi lebih berat dan lebih lama, bahkan lebih menyakitkan. Tetapi biasanya semua gejala ini akan lenyap dengan sendirinya sesudah tiga bulan. ${ }^{66}$

Dari hasil penelitian di atas, bahwa metode KB yang di pakai juga membawa efek samping terhadap kesehatan bagi akseptor KB kesehatan akan terganggu seperti batuk, badan menjadi gemuk, dapat membuat seorang perempuan tidak segera hamil, terjadi keputihan hebat, haidnya kadang tidak teratur. Sedangkan implikasi negatif KB dalam membentuk keluarga sakinah apabila kesehatan terganggu akan menjadi faktor penghalang untuk dapat mewujudkan keluarga sakinah Salah satu cara dalam mewujudkan keluarga sakinah yaitu terpenuhinya kebutuahan kesehatan keluarga. Secara sederhana yang dimaksud dengan pengertian kesehatan ialah terpenuhinya kebersihan dalam arti kata bebas dari gangguan penyakit macam penyakit. Kesehatan dalam arti luas bukan hanya sehat fisik (jasmani) tetapi juga sehat psikis (rohani, jiwa) dan sosial (Masyarakat).

Rohani sehat tetapi jasmani sakit, maka lambat laun rohani itu akan menderita sakit pula. Ajaran Islam telah memberikan tuntunan kepada umatnya untuk selalu memelihara kesehatan hidup, sehingga menurut pandangan Islam kebersihan yang merupakan pangkal kesehatan itu ditempatkan sebagai salah satu cabang keimanan seorang Nadhofatu minal iman (kebersihan itu sebagian dari iman). Hal ini menunjukkan betapa pentingnya memelihara kesehatan itu memelihara kesehatan termasuk satu kewajiban yang diperintahkan agama.

${ }^{66}$ Ibied, 
Usaha-usaha untuk memelihara kesehatan itu ada dua cara. Yakni tindakan yang bersifat pembasmian (kuaratif) dan tindakan yang bersifat pencegahan (preventif). Contoh tindakan yang bersifat kuratif : apabila badan kita terasa sakit sehingga menggangu normalitas gerak tubuh, segeralah datang ke dokter. Janganlah sekali-kali membiarkan sakit walaupun hanya penyakit ringan, sebab apabila dibiarkan tanpa mendapat pertolongan pengobatan, penyakit itu akan bertambah parah. Sedaangkan contoh tindakan yang bersifat preventif yaitu Menjaga kebersihan badan dan pakaian, Apabila terjangkit suatu wadah penyakit hendaklah segera mengadakan vaksinasi dan beserta imunisasi terhadap penyakit tersebut, Memiliki pengetahuan dasar dalam pemeliharaan kesehatan dan pengobatan ringan (P.3.K), Mengatur makanan yang sehat, Berolahraga secara teratur dan kontinyu, Istirahat yang cukup .

Peranan musyawarah dalam keluarga sangat penting, seperti hak berpendapat bersama dalam keluarga pada isteri dalam mengikuti progam KB sebaiknya menggunakan metode apa yang cocok dan aman, agar terhindar dari penyakit. Kesulitan akan hilang bila dilakukan diskusi dengan akal sehat serta keterbukaan yang jujur untuk dapat disepakati rumusan pemecahaan yang dititik beratkan pada kemaslahatan bersama.

Implikasi negatif lain KB dalam pembentukan keluarga sakinah di lihat dari segi psikologisnya seperti yang di ungkapkan oleh pasangan bapak KH. Hasyim Yusuf dan ibu nyai $\mathrm{Hj}$. Lathifah Hidayati. Ibu nyai $\mathrm{Hj}$. Lathifah menjawab:

"Gimana ya, justru ketika saya merasakan saya KB itu justru was-was mbak, ya saya merasakan was-was, was-was sekali ngunu. jadi apalagi ketika namanya suami istri ya pasti melakukan hubungan suami istri jelas was-was gitu loh ndakndak nyaman gitu loh, kalau positif ya saya belum menemukan itunya karena apa karena saya hanya pekek 3 bulan sudah saya ambil lagi karena saya tidak nyaman gituloh padahal saya ambil yang terbaik untuk 9 tahun IUDnya itu untuk 9 tahun hanya 3 bulan sudah saya lepas karena ndak nyaman perasaan itu ndak nyaman, jadi menurut saya membikin tidak harmonis kan perasaankan perasaan tidak enak gitu loh was-was kan gak enak gitu loh, meskipun hakikatnya di dalam tempatnya di dalam daerah tersebut tapi tetep ae rasanya ndak nyaman". 67

Kemudian ketika peneliti menanyakan hal ini kepada suami beliau yaitu bapak KH. Hasyim Yusuf, beliau menjawab: "Kejiwaan juga sering marah dan lain-lain itu adalah dampak negatif KB. Dampak positifnya sangat sedikit sekali toh (kan) banyak yang KB ketidak berhasilannya sudah tidak punya anak, tapi yang jelas dampak negatifnya sangat banyak sekali". 68

\footnotetext{
${ }^{67}$ Ibu Nyai Hj. Lathifah Hidayati, Op, Cit.,

${ }^{68}$ Bapak KH. Hasyim Yusuf, Op, Cit.,
} 
Dari hasil penelitian di atas implikasi negatif KB dalam membentuk keluarga sakinah dilihat dari segi psikologisnya adalah membuat perasaan atau psikologisnya merasa tidak nyaman atau merasa tidak tenang, emosi kurang stabil dan menimbulkan rasa khawatir, karena perasaan khawatir dan tidak tenang itu menurut beliau dapat membuat tidak harmonis hal ini dituturkan oleh pasangan suami istri bapak $\mathrm{KH}$ hasyim Yusuf dan ibu nyai $\mathrm{Hj}$. Lathifah Hidayati.

Memang salah satu efek samping lainnya yang timbul karena menggunakan salah satu metode $\mathrm{KB}$ seperti menggunakan spiral atau IUD dapat menimbulkan rasa cemas ketika berhubungan seks, karena pasangan bisa merasakan adanya spiral ketika menggunakan spiral atau IUD tersebut. Di samping itu, hubungan seksual seperti ini juga tidak dapat memberikan kenikmatan dan tidak dapat mencapai orgasme yang sesungguhnya. Demikian pula dengan kondisi psikologis perempuan seperti cepat emosi, gulau, gundah gulana, dan pada akhirnya akan mengakibatkan rasa sakit yang sangat luar biasa saat bersenggama. Sehingga dapat mengakibatkan sikap frigid dalam berhubungan seksual karena hal ini dapat membuat seorang perempuan tidak pernah merasakan orgasme serta kenikmatan yang memuaskan dalam berhubungan seksual. ${ }^{69}$

Kebahagiaan seksual. Sudah menjadi fitrahnya, dalam kehidupan rumah tangga suami istri ingin meraih kepuasan seksual. Islam menuntunkan agar istri senantiasa bersiap memenuhi panggilan suami, tapi juga diajarkan agar suami selalu memperhatikan kebutuhan seksual istri. Ketika sepasang suami istri secara bersama dapat mencapai kepuasan seksual, maka mereka akan merasakan kebahagiaan seksual. Terlebih bila dari aktifitas seksual itu kemudian terlahir anak. Dengan pendidikan yang baik tumbuh menjadi anak yang shalih dan shalihah, kebahagiaan akan semakin memuncak.

Kenyamanan dalam keluarga hanya dapat dibangun secara bersama-sama. Tidak bisa bertepuk sebelah tangan. Melalui proses panjang, setiap anggota keluarga saling menemukan kekurangan dan kelebihan masing-masing. Salah satu kewajiban suami yaitu mewujudkan kehidupan perkawinan yang diharapkan Allah untuk terwujud, yaitu sakinah, mawaddah dan rahmah. Untuk maksud itu suami wajib memberikan rasa tenang bagi istrinya, memberikan cinta dan kasih sayang kepada istrinya. ${ }^{70}$

Dari penjelasan di atas dapat dikatakan bahwa salah satu perkara pendukung dalam membentuk keluarga sakinah adalah terciptanya rasa ketenangan dalam rumah tangga. Apabila rasa ketenangan tersebut tidak ada maka hal itu dapat berakibat adanya faktor

\footnotetext{
${ }^{69}$ Thariq At-Thawari, Op., Cit. 98.

${ }^{70}$ Amir Syarifuddin, Hukum Perkawinan Islam Di Indonesia, (Jakarta: Kencana, 2006), 161.
} 
pengahalang terwujudnya pembentuk keluarga sakinah dan pada akhirnya dapat menimbulkan perceraian. Tetapi karena informan ini memakai metode KB yakni menggunakan IUD hanya selama tiga bulan saja, maka beliau belum menemukan sisi positif KB. Meskipun beliau berpendapat demikian setidaknya KB membawa sisi kemaslahatan bagi keluarga terutama bagi kesehatan anak karena menyangkut alasan beliau dalam mengikuti KB di atas adalah untuk menyusui anaknya salama 2 tahun penuh. Maka dari alasan tersebut, tanpa disadari oleh beliau KB membawa pengaruh dan dampak yang positif kepada keluarga khususnya dalam mewujudkan keluarga sakinah.

Implikasi negatif KB dalam membentuk keluarga sakinah dari segi agama hanya ada satu keluarga saja yang mempunyai implikasi tersebut, di antranya yaitu: keluarga bapak KH. Hasyim Yusuf dan ibu nyai Hj. Lathifah Hidayati. Bapak KH. Hasyim menjawab yaitu: "Dampaknya ya luar biasa negatifnya diantaranya dengan KB itu kodrat tubuh wanita itu menjadi sangat sulit diajak ibadah karena apa menstruasi jadi bolak-balik".71

KB membawa dampak yang luar biasa negatifnya apabila ini berhubungan dengan agama yaitu mengenai tentang ibadah, di antaranya yaitu dengan KB kodrat tubuh wanita itu menjadi sangat sulit diajak untuk beribadah karena menstruasi yang tidak teratur, hal ini seperti yang dituturkan oleh bapak KH. Hasyim Yusuf. Memang tugas sebagai kepala dan pemimpin keluarga yaitu suami wajib mengajak istri dan anak-anaknya untuk beribadah kepada Allah. Melindungi dan menjaganya dari segala sesuatu yang mungkin melibatkannya pada sesuatu perbuatan dosa dan maksiat atau ditimpa oleh sesuatu kesulitan dan bahaya. Menjaga kehidupan beragama istrinya, membuat istrinya tetap menjalankan ajaran agama, dan menjauhkan istrinya dari segala sesuatu yang dapat menimbulkan kemarahan Allah. Untuk maksud tersebut suami wajib membimbing istri sebaik-baiknya, membina akhlak istri, memberikan pendidikan agama dan pendidikan lain yang berguna bagi istri dalam kedudukannya sebagai istri.

Umunya wanita dewasa mengalami haid pada setiap bulannya. Adapun bagi wanita yang sedang haid, tidak diperbolehkan melakukan ibadah dalam kata lain ibadah dalam bentuk pekerjaan yang telah ditentukan wujud perbuatannya ${ }^{72}$ seperti sholat, puasa, masuk masjid, membaca dan menyentuh Al-Qur'an, thawaf keliling Ka'bah dan bersetubuh. Maka dari sinilah dapat di pahami bahwa implikasi KB dalam membentuk keluarga sakinah tidaklah membawa dampak yang luar biasa negatif apabila ini berhubungan dengan agama

\footnotetext{
${ }^{71}$ Bapak KH. Hasyim Yusuf, Op, Cit.,

${ }^{72}$ Ahmad Thib Raya dan Siti Musdah Mulia, Menyelami Seluk Beluk Ibadah Dalam Islam, (Bogor: Kencana, 2003), 138.
} 
yang menyangkut tentang ibadah seperti dengan mengikuti KB kodrat tubuh wanita itu menjadi sangat sulit diajak untuk beribadah karena haid yang tidak teratur.

Jadi menurut pendapat bapak KH. Hasyim ini tidak dapat dibenarkan bahwa kalau implikasi negatif KB dalam membentuk keluarga sakinah dilihat dari segi agama yaitu kodrat tubuh wanita menjadi sulit untuk diajak beribadah karena haid yang tidak teratur. Wanita juga mempunyai kodrat lain yaitu setiap bulannya mengalami haid. Adapun sebab terjadinya haid adalah karena fitrah atau pembawaan belaka yang dianugrahkan Allah kepada kaum wanita anak cucu Adam. ${ }^{73}$ Justru dengan mengikuti KB seperti menkonsumsi pil KB untuk tujuan ibadah seperti melakukan ibadaha haji sangat membantu bagi keberlangsungan ibadah tersebut. Dari hasil penelitian ini dapat diketahui bahwa ternyata KB membawa implikasi positif dan negatif dalam membentuk keluarga sakinah, baik di lihat dari segi kesehatan, ekonomi, psikologis, agama dan pendidikan.

Keluarga sakinah adalah suatu keluarga yang dibina atas perkawinan yang sah, mampu memenuhi hajat hidup spiritual dan material secara layak dan seimbang, diliput suasana kasih sayang antara anggota keluarga dan lingkungannya dengan selaras, serasi, serta mampu mengamalkan, menghayati, dan memperdalam nilai-nilai keimanan, ketakwaan, dan akhlak mulia. Ketika sebuah keluarga terpenuhi segala kebutuhannya baik secara materiil maupun spirituil, dan terjamin dari kesehatan, ekonomi, psikologis, agama dan pendidikan maka dengan sendirinya keluarga tersebut akan terbentuk menjadi sebuah kelarga yang sakinah mawaddah dan rahmah.

\section{F. Kesimpulan}

Keluarga-keluarga pesantren yang melakukan KB mempunyai alasan-alasan untuk membentuk keluarga yang lebih baik lagi. Ciri-ciri keluarga yang sakinah di antaranya kehidupan keluarga berlandaskan agama, terpenuhinya segala kebutuhan baik materiil maupun non meteriil, pendidikan anak-anak terpenuhi, saling kasih, saling sayang, saling mengerti dan semua anggota mengerti akan hak dan kewajibannya. Begitu juga dengan keluarga pesantren yang melakukan KB, yaitu berusaha untuk memenuhi segala kebutuhan anggota keluarga, baik agama, ekonomi, psikologis, kesehatan maupun pendidikan anakanak. KB dapat mendukung terbentuknya kesakinahan dalam keluarga. Ketika dalam sebuah keluarga terpenuhi segalanya baik ajaran agama, ekonomi, kesehatan, pendidikan, saling kasih sayang dan mengerti, komunikasi atau musyawarah dan saling terpenuhinya hak dan kewajibannya maka dengan sendirinya kesakinahan keluarga akan terwujud.

\footnotetext{
${ }^{73}$ Anshori Umar, Fiqih Wanita (Semarang: CV. Asy-Syifa, 1986), 51.
} 


\section{DAFTAR PUSTAKA}

Al-Qur'an dan terjemahnya. 1992. Jakarta: Depertemen Agama.

Al-Anwar, Abu Zahroh. 2008. Untuk Yang Merindukan Keluarga Sakinah, Gresik: Pustaka Al-Furqon.

At-Thawari, Thariq. 2007. "KB Cara Islam”, Solo: PT. Aqwam Media Profetika.

Al-Munajjid, Muhammad Shalih. 2007. 40 Kiat Menuju Keluarga Sakinah Yogyakarta: Pustaka Fahima.

Junaedi, Dedi. 2007. Keluarga Sakina Pembinaan dan Pelestariannya, Jakarta: Akademika Pressindo.

Mahjudin. 2007. Masailil Fiqhiyah, Jakarta: Kalam Mulia.

Nasution, Khoiruddin. 2002. Membentuk Keluarga Sakinah, Yogyakarta: PSW IAIN Sunan Kalijaga.

Raya, Ahmad Thib dan Siti Musdah Mulia. 2003. Menyelami Seluk Beluk Ibadah Dalam Islam, Bogor: Kencana.

Shihab, M. Quraish. 2007. Pengantin Al-Qur'an Kalung Permata Buat Anak-anakku, Jakarta: Lentera Hati.

Subhan, Zaitunah. 2004. Membina Keluarga Sakinah Yogyakarta: Pustaka Pesantren.

Syarifuddin, Amir. 2006. Hukum Perkawinan Islam Di Indonesia, Jakarta: Kencana.

Umar, Anshori. 1986. Fiqih Wanita, Semarang: CV. Asy-Syifa.

Zuhdi, Masjfuk. 1997. Masail Fiqhiyah Jakarta: PT. Midas Surya Grafindo.

Amien, Aidil. "Persiapan Nikah Dan Menjaga Keharmonisan Pasca Nikah", http://ilovequ.wordpress.com/2008/01/01/menikah-sebuah-keniscayaan-menujuummatpilihan/, (diakses pada 18 Agustus 2008).Hassan Hathout, Panduan Seks Islami (Jakarta: Zahra, 2008).

BKKBN, "KB Tidak Bertentangan Dengan Ajaran Islam", http://www.bkkbn.go.id/gemapria/info.detail.php?infid=29 (diakses pada 08 Mei 2008).

Hakim, Abdul bin Amir Abdat, "Islam Menganjurkan Umatnya Untuk Mempunyai Banyak Anak", http://salafy.wordpress.com/2007/11/08/islam-menganjurkan-umatnya-untukmempunyai-banyakanak/, (diakses pada 08 Mei 2008).

Hujair Ah. Sanaky, "Keluarga Sakinah", http://www.sanaky.com/materi/KELUARGA_SAKINAH.pdf, (diakses pada 17 Oktober 2008). 
Iryanti, "Peran Orangtua dalam Mendidik Anak," http://www.pkpaindonesia. org/index.php?option=com_content\&view=article\&id=127:peran-orangtua alam mendidik-anak\&catid=58:artikel-aceh\&Itemid=171, (diakes pada 31 Maret 2009)

"Institusi Keluarga Dalam Islam", http://www.geocities.com/farouq1965/TPSM/1i.htm, diakses pada 08 Mei 2008)

"Keluarga Berencana", http://situs.kesrepro.info/kb/referensi.htm,, (diakses pada 08 Mei 2008).

"Kontrasepsi dalam tinjauan syar'i", http://islammuna.multiply.com/journal/item/15, (diakses pada 08 Mei 2008).

Majalah Al-Hijrah, "Konsep Keluarga Sakinah", http://www.google.co.id/m?mresrtrict=xhtml\&eosr $=0$ \& \& $q=$ kosnsep\%20keluarga\%20 sakinah, (diakses pada 17 Oktober 2008)

Syamsur, "Kiat-Kiat Membangun Keluarga Sakinah", $\underline{\text { http://madinah- }}$ alhikmah.net/modules/news/article.php?storyid=95:, (diakses pada 26 April 2008)

TEMPO, "Nahdlatul Ulama Dukung Krogram http://www.tempointeraktif.com/hg/nasional/2007/02/13/brk,2007021393086,id.html, (diakses pada 08 Mei 2008). 